\title{
Impact of change in erosion rate and landscape steepness on hillslope and fluvial sediments grain size in the Feather River basin (Sierra Nevada, California)
}

\author{
M. Attal ${ }^{1}$, S. M. Mudd ${ }^{1}$, M. D. Hurst ${ }^{1, *}$, B. Weinman ${ }^{2}$, K. Yoo ${ }^{2}$, and M. Naylor ${ }^{1}$ \\ ${ }^{1}$ School of GeoSciences, Univ. of Edinburgh, Drummond Street, Edinburgh, EH8 9XP, UK \\ ${ }^{2}$ Department of Soil, Water, and Climate, University of Minnesota, 439 Borlaug Hall, \\ 1991 Upper Buford Circle, St. Paul, MN 55108-6028, USA \\ *now at: British Geological Survey, Keyworth, Nottingham, NG12 5GG, UK
}

Correspondence to: M. Attal (mikael.attal@ed.ac.uk)

Received: 12 September 2014 - Published in Earth Surf. Dynam. Discuss.: 15 October 2014

Revised: 9 March 2015 - Accepted: 10 March 2015 - Published: 25 March 2015

\begin{abstract}
The characteristics of the sediment transported by rivers (e.g. sediment flux, grain size distribution GSD) dictate whether rivers aggrade or erode their substrate. They also condition the architecture and properties of sedimentary successions in basins. In this study, we investigate the relationship between landscape steepness and the grain size of hillslope and fluvial sediments. The study area is located within the Feather River basin in northern California, and studied basins are underlain exclusively by tonalite lithology. Erosion rates in the study area vary over an order of magnitude, from $>250 \mathrm{~mm} \mathrm{ka}^{-1}$ in the Feather River canyon to $<15 \mathrm{~mm} \mathrm{ka}^{-1}$ on an adjacent low-relief plateau. We find that the coarseness of hillslope sediment increases with increasing hillslope steepness and erosion rates. We hypothesise that, in our soil samples, the measured 10-fold increase in $D_{50}$ and doubling of the amount of fragments larger than $1 \mathrm{~mm}$ when slope increases from 0.38 to $0.83 \mathrm{~m} \mathrm{~m}^{-1}$ is due to a decrease in the residence time of rock fragments, causing particles to be exposed for shorter periods of time to processes that can reduce grain size. For slopes in excess of $0.7 \mathrm{~m} \mathrm{~m}^{-1}$, landslides and scree cones supply much coarser sediment to rivers, with $D_{50}$ and $D_{84}$ more than one order of magnitude larger than in soils. In the tributary basins of the Feather River, a prominent break in slope developed in response to the rapid incision of the Feather River. Downstream of the break in slope, fluvial sediment grain size increases, due to an increase in flow competence (mostly driven by channel steepening) as well as a change in sediment source and in sediment dynamics: on the plateau upstream of the break in slope, rivers transport easily mobilised fine-grained sediment derived exclusively from soils. Downstream of the break in slope, mass wasting processes supply a wide range of grain sizes that rivers entrain selectively, depending on the competence of their flow. Our results also suggest that, in this study site, hillslopes respond rapidly to an increase in the rate of base-level lowering compared to rivers.
\end{abstract}

1

In the rock cycle, clastic sediment is produced in upland mountainous areas. The type of sediment delivered from hillslopes to the fluvial system conditions the characteristics of the sediment that is transported by rivers and ultimately exported from mountain ranges to sedimentary basins (Knighton, 1982; Parker, 1991; Heller et al., 2001; Attal and
Lavé, 2006; Sklar et al., 2006; Chatanantavet et al., 2010; Whittaker et al., 2010; Bennett et al., 2014; Michael et al., 2014). The grain size distribution (GSD) within hillslope soils and weathering profiles exerts a strong control on hillslope hydrology (e.g. Lohse and Dietrich, 2005) and chemical weathering rates by modulating particle surface areas (e.g. White and Brantley, 2003; Yoo and Mudd, 2008) and water residence time (Maher, 2010). In bedrock rivers, sedi- 
ment flux and GSD affect the ability of rivers to erode their substrate in two ways: they control (i) the availability and effectiveness of tools for bedrock erosion and (ii) the extent of the protective alluvial cover that the rivers need to mobilise during floods for erosion to happen (e.g. Gilbert, 1877; Sklar and Dietrich, 2004; Cowie et al., 2008; Hobley et al., 2011). They also control the architecture and properties of the stratigraphic successions in sedimentary basins, because the distance travelled by sediment particles before being deposited is dictated primarily by their grain size (e.g. Duller et al., 2010; Whittaker et al., 2010; Armitage et al., 2011). In the short term, fluvial sediment flux and GSD condition whether a river aggrades or incises, both in upland areas and throughout sedimentary basins (e.g. Lane et al., 2007; Duller et al., 2010). This point is of particular relevance when considering the impact of climate change and land use on river dynamics and human infrastructures within river basins, since both changing climate and land use modify sediment and water fluxes from hillslopes to rivers, with a potentially negative impact on the capacity of rivers to hold water within their channels (Lane et al., 2007).

The GSD of the sediment supplied to rivers is one of the main controls on the characteristics of the sediment transported by rivers (i.e. GSD, bedload-to-total-load ratio and lithologic content), the other main controls being abrasion, selective transport and sediment fluxes from hillslopes (Wolcott, 1988; Attal and Lavé, 2006; Sklar et al., 2006; Whittaker et al., 2010). Numerical models suggest that, in areas where rivers are actively incising into bedrock and net deposition is negligible, the continuous supply of fresh material from hillslopes in uniformly eroded landscapes may offset the reduction in grain size by abrasion and prevent downstream fining (Attal and Lavé, 2006; Sklar et al., 2006). Models have also shown that spatial variations in the grain size of the sediment supplied to rivers could have a significant impact on the GSD of the sediment in the river: whereas the effect of a coarser point source would vanish a few kilometres downstream of the location of the point source (Sklar et al., 2006), a general coarsening or fining of the sediment supplied to the river over a given area would lead to significant and potentially abrupt coarsening or fining of the fluvial sediment, which could persist downstream for kilometres (Attal and Lavé, 2006; Sklar et al., 2006). These model results have been corroborated by field observations in rivers in the Himalayas and in the Apennines (Attal and Lavé, 2006; Whittaker et al., 2010). However, whereas sediment fluxes from hillslopes have been quantified in many places over a range of time scales (e.g. Brown et al., 1995; Bierman and Steig, 1996; Granger et al., 1996; Hovius et al., 1997; West et al., 2005), little is known about the GSD of the sediment being delivered to rivers and about the controls upon it (Wolcott, 1988; Casagli et al., 2003; Attal and Lavé, 2006; Whittaker et al., 2010).

In non-glaciated areas, previous studies have shown that differences in hillslope steepness are associated with differ- ences in hillslope processes: as gradient increases, shallow hillslope erosion processes, e.g. ravelling and creeping, are replaced by "steep-slope" erosion processes, e.g. landslides, rock fall and formation of large scree cones. Such observations have been made in varied landscapes and contrasting climatic settings (e.g. San Gabriel Mountains, California Lavé and Burbank, 2004; Nanga Parbat massif, Himalayas Burbank et al., 1996; Oregon Coast Range, Oregon - Roering et al., 1999) and are consistent with the results of experimental studies of hillslope sediment transport (Roering et al., 2001). Furthermore, initial data from one catchment in the Apennines (Whittaker et al., 2007, 2010) suggest that erosion processes operating on steep hillslopes provide coarser material to the fluvial system than erosion processes operating on gentle hillslopes. Lavé and Burbank (2004) made similar qualitative observations in California. In addition, Attal and Lavé (2006) showed that lithology exerts a major control on the GSD of the sediment supplied by landslides to the Marsyandi River (Nepal, Himalayas). However, most of these observations are qualitative, and the few studies that produced detailed GSD of the sources of sediment for rivers focused either on landslide deposits (Casagli et al., 2003; Attal and Lavé, 2006; Whittaker et al., 2010) or soils (Marshall and Sklar, 2012).

This study proposes to bridge this gap by assessing the impact of increased erosion rates and associated slope steepening on sediment characteristics, both on hillslopes and in rivers. The study area is the Feather River basin (California), which comprises both low- and high-relief areas with erosion rates varying over an order of magnitude, from $>250 \mathrm{~mm} \mathrm{ka}^{-1}$ in the steepest parts of the landscape to $<15 \mathrm{~mm} \mathrm{ka}^{-1}$ on the low-relief plateau (Riebe et al., 2000; Hurst et al., 2012). This morphological contrast results from the rapid incision of the Feather River in response to a relative drop in base level, causing the formation of a deep gorge (Fig. 1). Tributary basins are still responding to the relative drop in base level and typically exhibit a topographic break in slope separating a low-relief relict topography (plateau) from a steepened landscape (Figs. 1 and 2). Hillslope and river sediment characteristics were measured both on the plateau and downstream of the main topographic break in slope in a series of tributary basins to identify potential changes in sediment sources and to assess the impact of changes in source and variations in channel slope on the characteristics of the sediment transported by rivers.

After a description of the study area and methods, we present the GSD data for the hillslope sites (sources) and for the fluvial sites. In light of these data, we analyse the relationships between source and fluvial sediment characteristics and discuss the potential links between tectonics, slope steepness, and sediment delivery and transport in mountain rivers. 

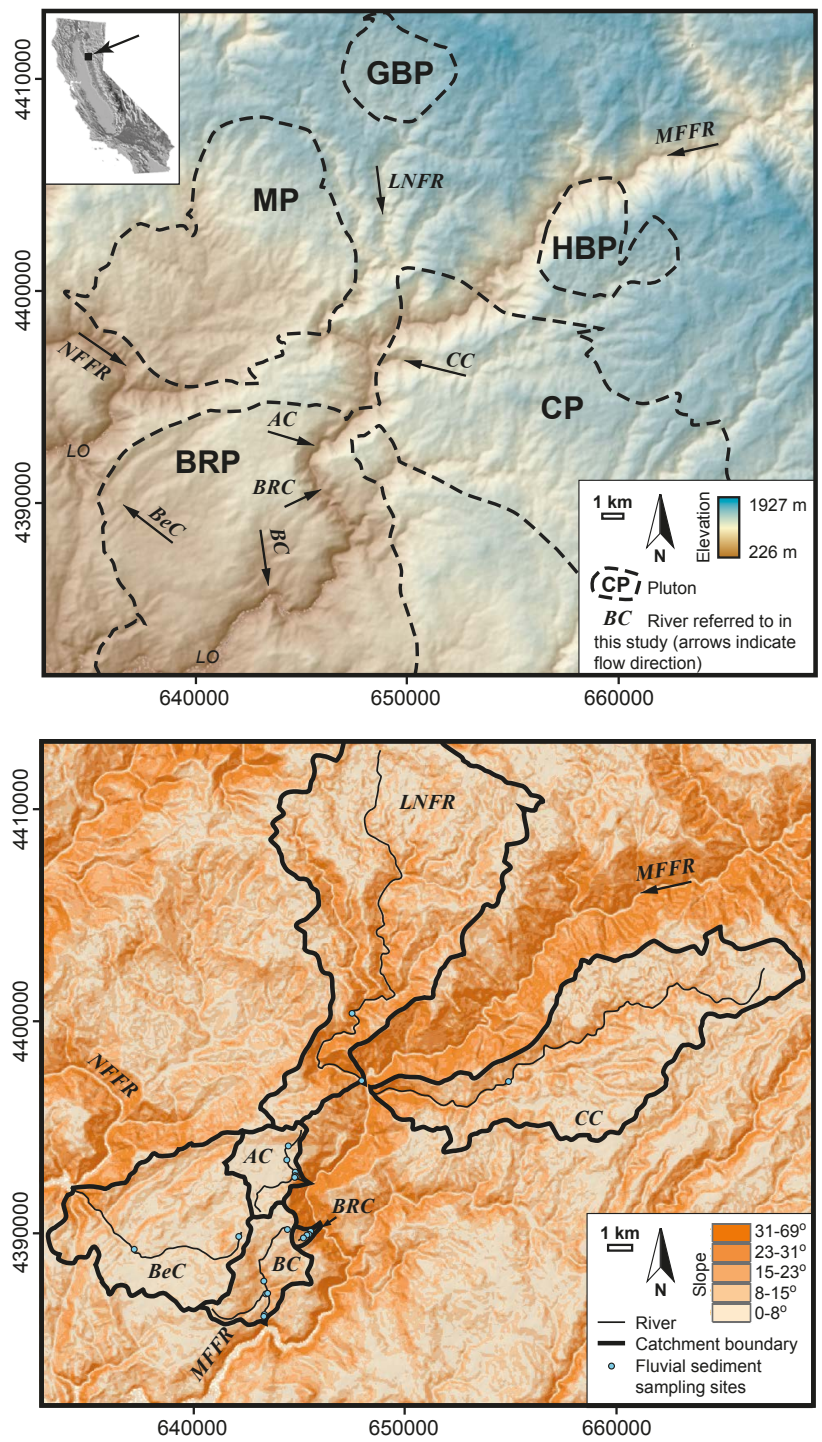

Figure 1. Overview of study area. Topographic data from USGS (National Elevation Dataset). The spatial reference system is UTM Zone $10 \mathrm{~N}$ with units in metres. Top panel: shaded relief of the study area showing the distribution of the Mesozoic plutons (from Geological map of the Chico Quadrangle; Saucedo and Wagner, 1992) and the studied rivers. Inset shows location of study area in California. Plutons (bold): BRP - Bald Rock; CP - Cascade; GBP - Granite Basin; HBP - Hartman Bar; MP - Merrimac. Rivers (bold italic): AC - Adams Creek BC - Bean Creek; BeC - Berry Creek; BRC Bald Rock Creek; CC- Cascade Creek; LNFR - Little North Fork River; MFFR - Middle Fork Feather River; NFFR - North Fork Feather River. LO - Lake Oroville. Bottom panel: slope map of the study area draped on shaded relief, showing boundaries of studied basins and sampling sites.

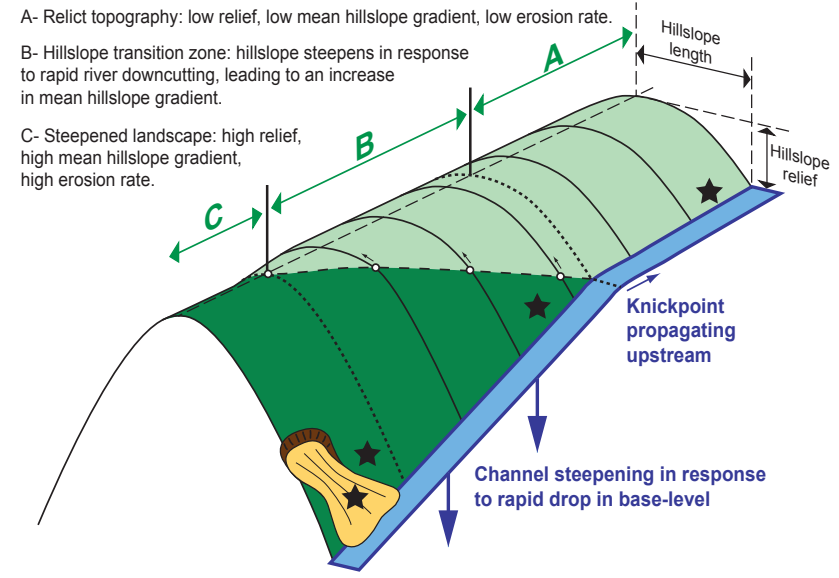

Figure 2. Schematic illustrating the typical morphology of the Feather River's tributary basins (adapted from Hurst et al., 2012). In response to a rapid drop in base level, a knickpoint propagates upstream along the channel, separating the steepened landscape from the relict topography. A break in slope also propagates up the hillslopes (dots with arrows) in response to the increase in channel downcutting rate. Stars schematically represent the location of sampling sites with respect to morphological domains: on the relict topography (domain A, site identifier POMD), in the transition zone where the hillslopes have not completely adjusted (domain B, site identifier FTA) and in the steepened area below the break in slope (domain $\mathrm{C}$, site identifier BRC and BRB for soils and LD for landslides). Note that the width of domain $\mathrm{B}$ is a function of the response time of the hillslopes (the shorter the response time, the narrower the domain B). The mean hillslope gradient $S_{\mathrm{h}}$ used in this study is the ratio of hillslope relief to hillslope length (shown on figure).

\section{Study area and methods}

This study focuses on basins draining an area where Mesozoic plutons have intruded a metamorphic basement, east of Lake Oroville, in the Sierra Nevada of California (Fig. 1). In response to an increase in the rate of base-level lowering, the origin and timing of which are still debated (Wakabayashi and Sawyer, 2001; Stock et al., 2004; Gabet, 2014), the North Fork and Middle Fork Feather rivers have formed gorges up to $600 \mathrm{~m}$ deep (Fig. 1). These gorges dissect a relict low-relief landscape (Fig. 1) that has erosion rates an order of magnitude lower than the gorges: cosmogenic radionuclide-derived erosion rates in basins draining the Bald Rock and Cascade plutons vary from $14.4 \pm 1.6 \mathrm{~mm} \mathrm{ka}^{-1}$ on the plateau to rates in excess of $250 \mathrm{~mm} \mathrm{ka}^{-1}$ in the steepest parts of the landscape (Riebe et al., 2000 - see samples within their "Fall River" area; Hurst et al., 2012). Many of the tributary basins which drain from the relict surface to the North and Middle Fork Feather rivers have been left hanging (Figs. 1 and 2): these basins typically exhibit a prominent convexity on their hillslopes and river profiles, marking the boundary between the lower basin which has steepened in response to the increase in the rate of base-level drop and the 
upper basin which has not yet detected the change in baselevel lowering rate (Figs. 1 and 2) (e.g. Whipple and Tucker, 2002; Crosby and Whipple, 2006; Whittaker et al., 2008; Attal et al., 2008, 2011). We have measured hillslope and fluvial sediment characteristics in tributary basins that drain the Bald Rock and Cascade Pluton, where the source rock lithology is predominantly tonalite (Fig. 1) (Saucedo and Wagner, 1992). The fluvial data set was complemented with sites in two large tributaries of the Feather River: Cascade Creek, which incises into the Cascade Pluton in the lower half of its course, and Little North Fork River, which mostly drains the metamorphic basement intruded by the Mesozoic plutons. Both basins show signs of transience (break in slope on hillslopes and along the river) and were investigated to assess whether their behaviour was consistent with the one exhibited by the smaller basins in response to the increase in the rate of base-level lowering.

\subsection{Sources of sediment for the rivers}

Sources of sediment in the study area comprise soils from soil-mantled hillslopes on the low-relief plateau and patchy soils, landslide deposits, scree cones and debris-flow deposits in the steep, incised valleys near the Feather River. Evidence for rock failures of various dimensions, from individual fragments to the release of hundreds of cubic metres of debris, is widespread on slopes above $0.7 \mathrm{~m} \mathrm{~m}^{-1}$. No recent debris flows were documented in the study area, but evidence of past debris flows was found along rivers in the steepened landscape below the prominent topographic break in slope. However, the GSD of the debris-flow deposits found in the field could not be characterised because these had undergone substantial reworking after their emplacement. All source sites were chosen on the Bald Rock tonalite pluton, identified by both field observations and geological map (Saucedo and Wagner, 1992). Sampling and measurement methods are similar to the ones used by Attal and Lavé (2006) (see below).

All soil sampling sites are located in the Bald Rock Creek basin (Figs. 1 and 3). Soil pits were dug along hillslope transects in three morphologically distinct areas (Figs. 2 and 3): on the relict topography above the break in slope (POMD, mean hillslope gradient $S_{\mathrm{h}}=0.38 \mathrm{~m} \mathrm{~m}^{-1}$ ), in the transition zone where the hillslopes have not completely adjusted to the base-level fall (FTA, $S_{\mathrm{h}}=0.67 \mathrm{~m} \mathrm{~m}^{-1}$ ) and below the break in slope (BRC and BRB, $S_{\mathrm{h}}=0.75$ and $0.84 \mathrm{~m} \mathrm{~m}^{-1}$, respectively); the mean hillslope gradient $\left(S_{\mathrm{h}}\right)$ represents the ratio of hillslope relief over the horizontal length of the hillslope (Fig. 2), which is a reliable proxy for erosion rate in this area (Hurst et al., 2012). At or below the break in slope (FTA, BRC and BRB), we found that the soils lack distinct illuvial B horizons. In contrast, redder soils with slightly clay-enriched B horizons were present above the break in slope (POMD). The soils in the area belong to either sandyskeletal, mixed, mesic Lithic Xerorthents (Waterman Series)

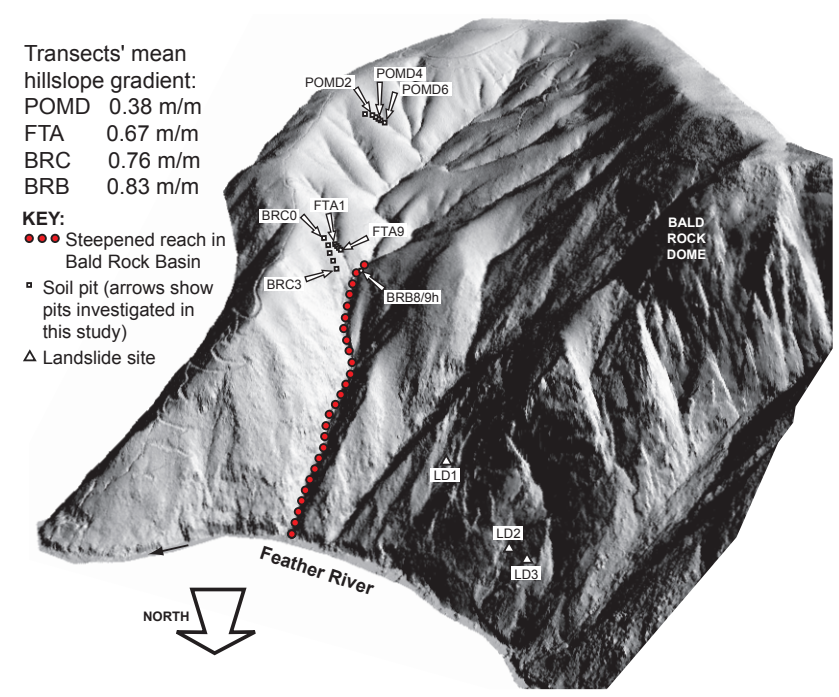

Figure 3. Shaded relief of Bald Rock basin derived from lidar (1 m resolution) data, showing the location of the soil and landslide sites. Horizontal length of steepened reach is $\sim 550 \mathrm{~m}$.

or coarse-loamy, mixed, superactive, mesic Typic Dystroxerepts (Chaix Series) (Soil Survey Staff, accessed 13 February 2015). At each site, soil pits were excavated to the depth of $20-30 \mathrm{~cm}$ below the soil-saprolite boundary. The material extracted from the pits was sieved in the field using 10, 20 and $40 \mathrm{~mm}$ square mesh sieves (Fig. 4a and b). Each fraction was weighed using a portable scale (accuracy $=20 \mathrm{~g}$ ), and fragments larger than $80 \mathrm{~mm}$ were weighed individually. Large fragments were found to be very lightly weathered; the size of the fragments larger than $80 \mathrm{~mm}$ was thus calculated assuming that they were spheres with a density of $2650 \mathrm{~kg} \mathrm{~m}^{-3}$. Approximately $1 \mathrm{~kg}$ of the fraction finer than $10 \mathrm{~mm}$ was sampled, and its GSD was determined in the lab using 8, 5.6, 4, 2.8, 2, 1.4 and $1 \mathrm{~mm}$ square mesh sieves. The GSD of the fraction finer than $1 \mathrm{~mm}$ was determined using a Malvern laser grain size analyser. At the soil sampling sites, the mass of sediment sieved and weighed ranged between 122 and $550 \mathrm{~kg}$ per pit, except at one site, where the soil was thin compared to the other sites and the soilsaprolite boundary was reached quickly: $63 \mathrm{~kg}$ of sediment was dug out and sieved at the steepest Bald Rock site (BRB, $S_{\mathrm{h}}=0.84 \mathrm{~m} \mathrm{~m}^{-1}$ ) (Fig. 3).

Landslide deposits and scree cones were investigated exclusively east of the Bald Rock Dome, immediately north of the Bald Rock Basin, where vegetation is scarce and debris are being actively accumulated below the rocky face (Figs. 3 and $4 c$ ). This was the only location where an active landsliding area could be accessed safely in the study area. The three sampling points are located in places where the debris accumulation has been cut by gullies or by the path, providing a clear cut through the deposit. LD1 is located at mid-height in a debris fan, whereas LD2 and LD3 are situated near the top of landslide fans. The surface material was removed down to 

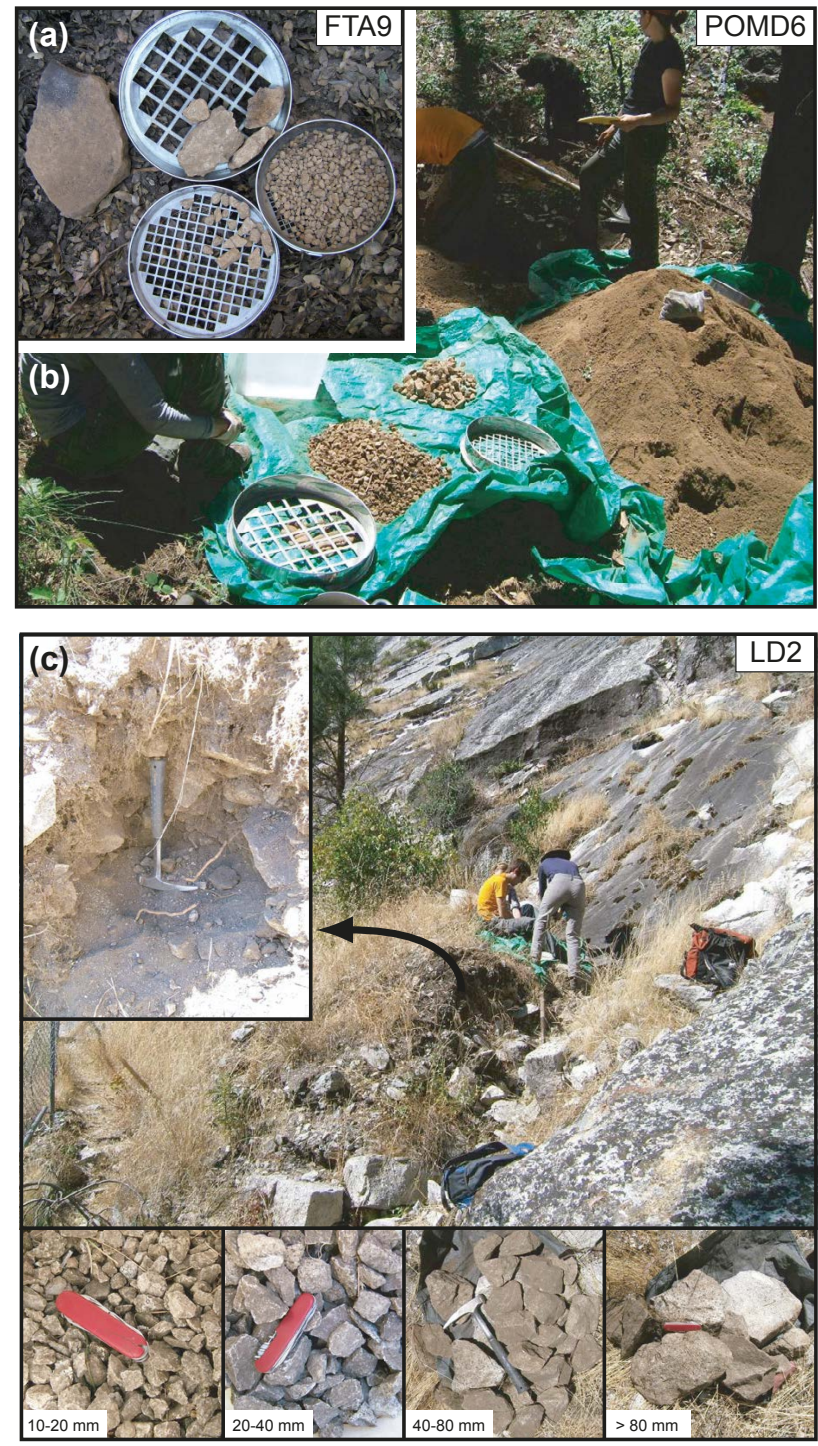

Figure 4. Photographs of hillslope sites (see Fig. 3 for location of sites). Panels (a) and (b): sediment at soil sites and 10, 20 and $40 \mathrm{~mm}$ square mesh sieves. (a) Sediment coarser than $10 \mathrm{~mm}$ at site FTA9 (transition zone); clasts are fresh and angular and show little evidence of chemical weathering. (b) Sediment at site POMD6 (plateau), including $540 \mathrm{~kg}$ of sediment finer than $10 \mathrm{~mm}$ (heap to the right), and 7.5 and $3.0 \mathrm{~kg}$ of clasts in the fractions 10-20 and 20$40 \mathrm{~mm}$, respectively (on the tarpaulin). (c) Sediment at the landslide site LD2. Upper panel: overview with close-up of pit (inset). Lower panel: different sediment fractions extracted from the pit. Hammer is $300 \mathrm{~mm}$ long. Swiss army knife is $90 \mathrm{~mm}$ long.

the depth of the largest clast exposed in the vicinity of the site to avoid bias caused by winnowing of the surface or kinetic sieving during landsliding. Eighty-five to $115 \mathrm{~kg}$ of sediment was dug out, sieved and weighed (Fig. 4c). The procedure for determining the GSD of the landslide sediment in the field and in the lab is identical to the one applied to soil material (see above).
Additionally, photographs of the surface of the scree cones and landslide deposits were taken at various locations below Bald Rock Dome. The field of each photograph was typically 1 to $2 \mathrm{~m}$ wide and high. A scale was placed at the centre of the field before each photograph was taken. These images were then used to determine GSD: following Kellerhals and Bray (1971), a regular square grid with 100 line intersections was placed on each photograph and the smallest axis of the clast at each intersection was measured. Clasts within the landslide deposits have no preferential orientation, which means that the length of the smallest axis measured on the photograph is a minimum estimate of the intermediate axis of the clasts. However, tonalite clasts were typically found to be neither elongated nor platy (Fig. 4c), thus limiting the deviation between the length measured on the photograph and the actual length of the clast's intermediate axis. Following Kellerhals and Bray's (1971) recommendation based on the voidless cube model, clasts covering $n$ grid intersections were counted $n$ times. According to this model, the GSD by number obtained from the photographs is directly comparable to the GSD by mass derived from the volumetric samples. The limitations associated with this model are discussed further (Sect. 2.3).

\subsection{Fluvial sediment}

The methods used to determine the GSD of fluvial sediment are similar to the ones used by Attal and Lavé (2006). Gravel bars were identified along the studied rivers, including the river basin where soil sediment was investigated (Figs. 1, 5 and 6). We focused on material that had been unambiguously transported by fluvial processes and avoided lag deposits found where old debris-flow or landslide deposits had been reworked (these latter deposits are characterised by extremely coarse sediment with locked, moss-covered particles that are indicative of low mobility). Surface and subsurface were distinguished to account for the armouring that typically characterises fluvial deposits (Bunte and Abt, 2001). Surface GSD was determined by photo analysis (see previous paragraph); because pebbles tend to lie preferentially with their small axis perpendicular to the surface of the gravel bar, the smallest visible axis on the photograph was considered as the intermediate axis of the pebble. Subsurface sediment was excavated from a pit after removing the surface material over an area of approximately 0.5 by $0.5 \mathrm{~m}$. This subsurface material was subjected to the same sieving and weighing procedure as the soil samples (see Sect. 2.1). We maximised the amount of sediment sieved with respect to the size of the largest clast at each site, but our efforts were restricted by the size of the gravel bars in these mountainous settings: some of the bars were small $\left(<2 \mathrm{~m}^{2}\right)$ and bounded by bedrock, which reduced the volume of sediment available for sieving. We were also unable to dig deep below the water level. The mass of sediment sieved and weighed at each site typically ranged between 23 and $154 \mathrm{~kg}$. 

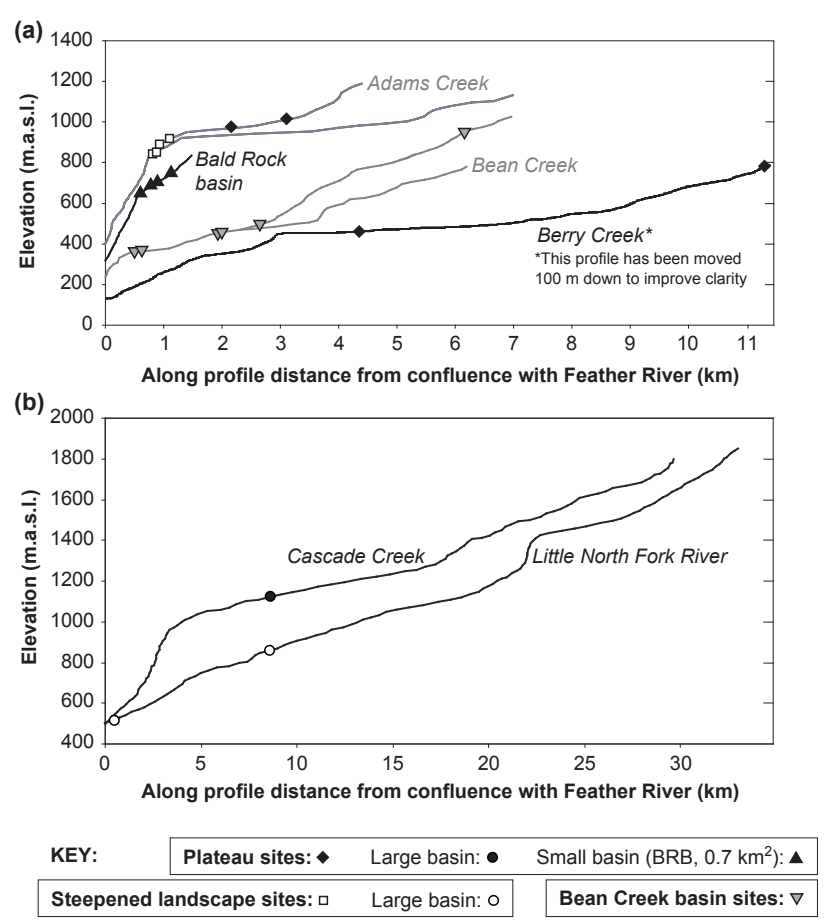

Figure 5. Long profiles of the studied rivers with location of the sampling sites for fluvial sediment. (a) Small tributary basins of the Feather River (length $<12 \mathrm{~km}$ ). (b) Two large tributaries of the Feather River (note change in scale on the $x$ axis). We classify sites based on their position with respect to the topographic break in slope (see key); Bean Creek sites are treated separately due to the lack of a clear morphological distinction between relict surface and steepened landscape.

Most of the rivers investigated have a large convexity on their long profile which marks the transition from the relict topography to the steepened landscape downstream (Figs. 1, 2 and 5). Along-stream variations in fluvial sediment GSD were determined in three basins draining the tonalite pluton: measurements were performed at four sites in Bald Rock basin and at six sites in Bean Creek and Adams Creek basins (Figs. 1 and 5a). Additional measurements in adjacent basins on the pluton were carried out on the plateau (Berry Creek basin) (Figs. 1 and 5a). Measurements in large rivers draining multiple lithologies were carried out on the plateau (Cascade Creek) and in the gorge (Little North Fork River) (Figs. 1 and $5 b)$.

In the following analysis and discussion, we will distinguish "plateau" sites from "steepened landscape" sites (Fig. 5). Bean Creek sites will be treated separately due to the absence of a clear morphological boundary between plateau and incised landscape.

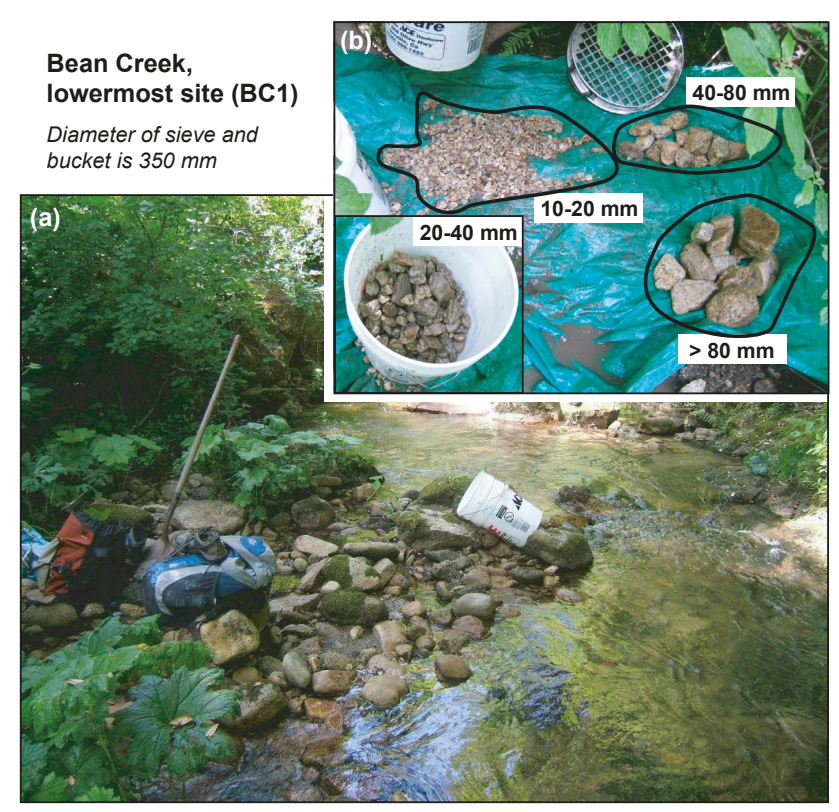

Figure 6. Example of gravel bar investigated in this study (site BC1 on Bean Creek). (a) Overview and (b) sediment after sieving.

\subsection{Sampling method bias and precision of measurements}

Many sample-size recommendations have been made for representatively sampling granular material (see extensive review in Bunte and Abt, 2001). For material typically coarser than $128 \mathrm{~mm}$, Church et al. (1987) recommend that the largest particle in a sample represents no more than $5 \%$ of the total mass of the sample to avoid unrepresentative positive skewness of the grain size distributions due to a few large clasts representing a large proportion of the total sample. Due to logistical and geomorphological constraints, this recommendation was not fulfilled at one of the soil sites, at all landslide sites and at more than half of the fluvial sites (see Tables A1 and A2 in Appendix).

To assess the impact of the largest clast representing an excessively large fraction of the volumetric sample on the determination of characteristic sediment grain sizes (i.e. median grain size $D_{50}$ and 84 th percentile $D_{84}$ ), the following procedure was applied. In the following example, the mass $m$ of the largest clast represents $n \%$ of the total mass of the sample. Firstly, the largest clast was removed from the distribution to estimate $D_{50}$ and $D_{84}$, had this large clast not been sampled; secondly, a large clast was added to the distribution, its mass calculated so that it represents $n \%$ of the mass of the new volumetric sample (we observe that in all cases, this calculated mass is 1 to 1.1 times the mass $m$ of the largest clast in the actual sample). This procedure gives a robust estimate of the potential variation in $D_{50}$ and $D_{84}$ induced by the inclusion or omission of large clasts in the sample (see Tables A1 and A2 in Appendix). In the follow- 
ing, error bars on grain sizes in figures represent the range of values between the two scenarios mentioned above rather than uncertainty, which cannot be calculated without a priori knowledge of the true grain size distribution or applying an inevitably imperfect model to represent this distribution.

Grid counts were performed on the surface of landslide and gravel bar sediment using photographic methods (see Sects. 2.1 and 2.2). The number of clasts counted on each photograph typically ranged between 65 and 100, due to the image being obscured by leaves, water or shadows in places (Table A2). Ideally, the size of the grid applied to the photographs should be chosen so that no more than one grid intersection falls on one sediment clast. Unfortunately, such a requirement is nearly impossible to fulfil at all sites in this mountainous setting where boulders larger than $0.5 \mathrm{~m}$ are present and gravel bars can sometimes be less than $2 \mathrm{~m}$ long. As mentioned above, clasts covering $n$ grid intersections were counted $n$ times, following Kellerhals and Bray's method (1971) based on the voidless cube model. Whereas Bunte and Abt (2001) agree that the voidless cube model may be applicable to armoured coarse gravel or cobble beds, thus allowing a direct comparison of grid-by-number and volumeby-mass samples (Kellerhals and Bray, 1971; Bunte and Abt, 2001), they highlight that multiple counting of particles overrepresents large particles and produces GSDs that are too coarse in their coarse part. The effect of multiple counting is minimal on $D_{50}$ but can be substantial on $D_{84}$ estimates. To assess the impact of large clasts covering $n>1$ grid nodes on the photographs on the determination of $D_{50}$ and $D_{84}$, we applied a similar procedure to the one used for the volumetric sample. Firstly, the largest clast was removed from the distribution to estimate $D_{50}$ and $D_{84}$, had this large clast not been sampled; secondly, a large clast similar in size to the largest clast in the actual sample was added to the distribution, covering the same number of grid nodes than this largest clast (Table A2). This procedure does not account for multiple clasts covering multiple nodes, but it gives a rough estimate of the variation in grain size potentially induced by the largest clast on the distribution, which is particularly significant for $D_{84}$ (Table A2) (Bunte and Abt, 2001). As with the volumetric samples, error bars on grain size in figures will represent the range of values between the two scenarios mentioned above.

\subsection{Flow competence and sediment grain size}

Flow competence dictates the maximum size of grains transported by a river for a given discharge. Competence is commonly expressed as a function of fluvial shear stress (e.g. Buffington and Montgomery, 1997), but this quantity is difficult to estimate in mountain rivers. Instead, an alternative approach involves the use of water discharge per unit flow width. According to theory and flume experiments, a power relationship (with an exponent $2 / 3$ in the case of uniform grain size) is expected between the grain size of the sed- iment entrained by a given water discharge $Q$ and the quantity $\omega_{m}=Q S^{M} / W$, where $S$ is channel slope, $W$ is channel width and $M$ is an exponent ranging between 1.12 and 1.17 (Schoklitsch, 1962; Bathurst et al., 1987; Whitaker and Potts, 2007; Bathurst, 2013) (note that $\omega_{m}$ would be proportional to specific stream power if $M$ were equal to unity). Measurements of the maximum grain size entrained in a series of natural rivers also show a power relationship with $Q / W$ for a given slope, thus supporting the theory (measurements were made at a given site over a range of discharges for each river: Whitaker and Potts, 2007; Bathurst, 2013).

Large variations in $\omega_{m}$ are expected along the rivers in the study area, in particular at the main topographic break in slope where both discharge and slope will increase downstream. In a situation where all grain sizes are potentially available for transport in the river, river sediment is expected to become coarser as $\omega_{m}$ increases, which we will assess in the following. For simplicity, we assume that (1) sediment in gravel bars is representative of the sediment that is typically transported during floods, (2) sediment in all the gravel bars investigated has been mobilised during an event of similar magnitude, and (3) fluvial sediment transport and subsequent deposition in gravel bars has occurred during floods resulting from storm events with no spatial variation in intensity across the entire study area. To maximise the validity of these assumptions, we consistently chose gravel bars that contained sediment that had been unambiguously transported by fluvial processes and that showed evidence of recent transport (i.e. we avoided bars with significant vegetation and/or moss cover). It is worth noticing that the climate in the study area is characterised by high seasonality, with $90 \%$ of the precipitation falling between October and April during storms lasting from a few hours to up to 10 days (see data for Brush Creek hydrologic station (BRS) located in the headwaters of the Adams Creek basin at latitude 39.692 and longitude -121.339; data accessed on 9 February 2015 on the California Data Exchange Center website at http://cdec.water.ca. gov/cgi-progs/stationInfo?station_id=BRS; maximum daily precipitation recorded since 1986 was $292 \mathrm{~mm}$ on 1 January 1997). This implies that sediment transport in the study catchments is likely to happen suddenly and synchronously during storms. We thus consider that discharge scales with drainage area $A$ (e.g. Snyder et al., 2003) and therefore assume that flow competence can be expressed as a function of $\omega_{m}^{\prime}=A S^{M} / W$; we use a value of $M=1.15$ as representative of the range of values published in the literature (between 1.12 and 1.17; e.g. Whitaker and Potts, 2007; Bathurst, 2013). Topographic metrics and river profiles were extracted from a $1 \mathrm{~m}$ resolution lidar-derived digital elevation model (DEM) obtained via the National Center for Airborne Laser Mapping (NCALM). The data were complemented by $10 \mathrm{~m}$ resolution topographic data from USGS (National Elevation Dataset) in three basins that were not entirely covered by the lidar data: Berry Creek, Cascade Creek and Little North Fork River. For each site, drainage area and channel slope were ex- 

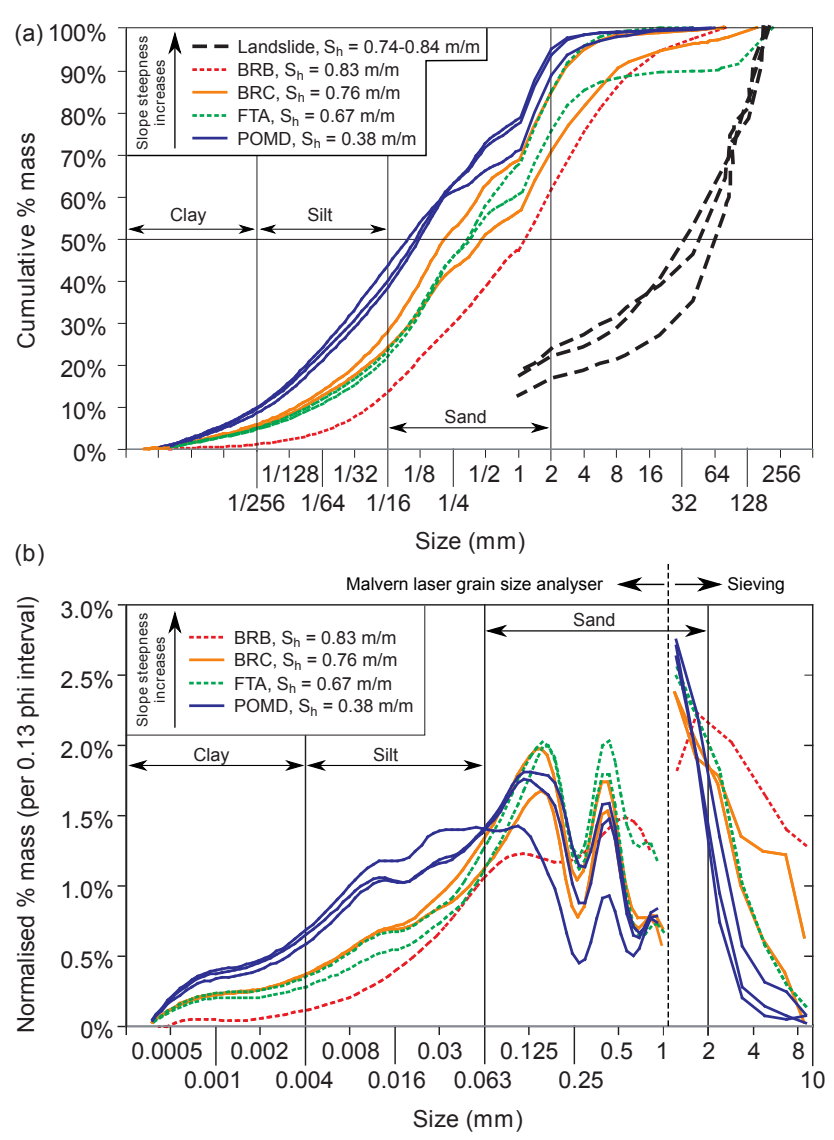

Figure 7. (a) Cumulative grain size distributions measured for the sources of sediment in Bald Rock basin (see sites location in Fig. 3). Line patterns reflect hillslope steepness at the sites $\left(S_{\mathrm{h}}\right.$ is mean hillslope gradient) and type of source (soil or landslide). Note the $\log _{2}$ scale on the $x$ axis. (b) Non-cumulative grain size distribution of the fraction finer than $10 \mathrm{~mm}$ of soil samples. Line patterns are the same as in (a). Grain size distributions of fraction coarser and finer than $1 \mathrm{~mm}$ were determined using sieves and a Malvern laser grain size analyser, respectively. For both methods, the percent mass has been normalised to represent the value per $0.13 \phi$ interval. Lines connecting the curves produced with the two methods (at $1 \mathrm{~mm}$ ) have been removed for clarity; the peak at the transition is real: sediment in the fraction $1-2 \mathrm{~mm}$ is significantly more abundant than sediment in the fraction $0.5-1 \mathrm{~mm}$. Note the $\log _{2}$ scale on the $x$ axis.

tracted from the $1 \mathrm{~m}$ resolution DEM, except for the Cascade Creek and lowermost Berry Creek sites, where the USGS DEM data were used instead (see Table A3 in Appendix). Slope was estimated over a 100-m distance; based on field observations, this distance, which represents between 5 and 50 channel widths, is deemed to reflect reach-scale geometry rather than the local pool and riffle morphology. Similarly, minimum and maximum channel widths were measured for each site over a 100-m long stretch on the lidar-derived DEM and Google Maps images: the mean width was used for the calculation of $\omega_{m}^{\prime}$ and the difference between mean and extrema was used as deviation for width.
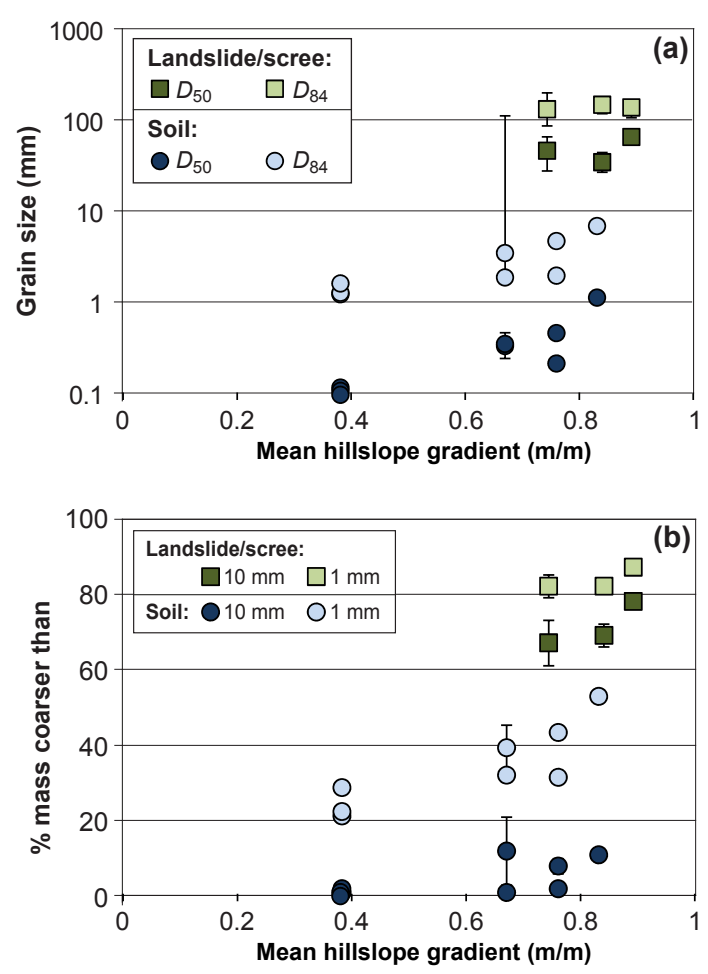

Figure 8. Grain size data for the sources of sediment: soils (circles) and landslides (squares). (a) Median grain size $D_{50}$ and 84 th percentile $D_{84}$ as a function of hillslope steepness. (b) Percent mass of the total sample finer than 1 and $10 \mathrm{~mm}$ as a function of hillslope steepness. Error bars represent plus or minus values calculated according to procedure described in Sect. 2.3.

\section{Results}

\subsection{Sources of sediment for the rivers}

Our results show that sediments from landslides and scree cones are significantly coarser than those from hillslope soils with no evidence of mass wasting (Figs. 7 and 8). For slopes steeper than $0.7 \mathrm{~m} \mathrm{~m}^{-1}$, mass wasting such as landsliding and formation of scree cones delivers sediment with grain sizes more than one order of magnitude larger than soils, as shown in median grain size $D_{50}$ and 84th percentile of the distribution $D_{84}$ (Figs. 7 and 8 a). Soils typically contain less than $12 \%$ mass of grains larger than $10 \mathrm{~mm}$, whereas fragments larger than $10 \mathrm{~mm}$ represent $\sim 70 \%$ mass of the landslide deposits investigated (Fig. 8b). When considering the cut-off size of $1 \mathrm{~mm}$ that separates material that can potentially be transported as suspended load from grains that will be transported as bedload, the difference is less accentuated but still substantial: landslide deposits contain around twice as much material coarser than $1 \mathrm{~mm}$ than soils do (Fig. 8b).

Furthermore, the type of source seems to influence the size of the largest particle to be supplied to the river: the size of the largest particle found in the soil pits is on average $89 \pm 64 \mathrm{~mm}$ ( \pm standard deviation), compared to 
Table 1. Statistical results for regression of $D=k\left(\omega_{m}^{\prime}\right)^{b}$ for Adams Creek data. $D$ is taken as $D_{50}, D_{84}$ and $D_{100}$, both for subsurface and surface samples. Results are highly significant for the exponent $b$ ( $p$ value $<0.01$ and high test statistic value $t$, except for $D_{100}$ for the surface samples), but $k$ is poorly constrained.

\begin{tabular}{|c|c|c|c|c|c|c|c|c|c|}
\hline Grain size & $b$ & $\begin{array}{c}\text { Standard } \\
\text { error }\end{array}$ & $t$ value & $p$ value & $\log k$ & $\begin{array}{c}\text { Standard } \\
\text { error }\end{array}$ & $t$ value & $p$ value & $\begin{array}{c}\text { Multiple } \\
R^{2}\end{array}$ \\
\hline$D_{50}$ sub. & 0.55 & 0.10 & 5.5 & 0.005 & -1.19 & 0.48 & -2.5 & 0.070 & 0.88 \\
\hline$D_{50}$ surface & 0.61 & 0.10 & 6.3 & $<0.001$ & -1.31 & 0.46 & -2.8 & 0.023 & 0.83 \\
\hline$D_{84}$ sub. & 0.43 & 0.06 & 7.0 & 0.002 & -0.16 & 0.29 & -0.6 & 0.611 & 0.92 \\
\hline$D_{84}$ surface & 0.53 & 0.08 & 6.8 & $<0.001$ & -0.55 & 0.37 & -1.5 & 0.176 & 0.85 \\
\hline$D_{100}$ sub. & 0.20 & 0.06 & 3.6 & 0.024 & 1.14 & 0.27 & 4.3 & 0.013 & 0.76 \\
\hline$D_{100}$ surface & 0.40 & 0.08 & 5.1 & $<0.001$ & 0.24 & 0.38 & 0.6 & 0.549 & 0.76 \\
\hline
\end{tabular}

$191 \pm 15 \mathrm{~mm}$ in the landslide deposits (Fig. 8a). In addition, GSD derived from 18 photos of the surface of landslide deposits in the Bald Rock Dome area yielded $D_{50}$ and $D_{84}$ values of $81 \pm 84$ and $187 \pm 126 \mathrm{~mm}$, respectively; this indicates that surface landslide GSD is spatially highly variable and that boulder-size fragments are widespread within the landslide deposits, despite them not being found in the pits we dug. The GSD of the measured landslide deposits falls within the range of GSD measured by Casagli et al. (2003) in areas underlain by turbidites and shales in the Apennines and by Attal and Lavé (2006) in areas underlain by quartzites, gneiss and schists along the Marsyandi River (Himalayas).

Within the soils, data from the Bald Rock basin seem to indicate an increase in $D_{50}, D_{84}$ and fractions coarser than 1 and $10 \mathrm{~mm}$ with increasing transect slope steepness (Fig. 8). The difference in $D_{50}$ between soils on slopes with gradients of 0.38 and $0.83 \mathrm{~m} \mathrm{~m}^{-1}$ is an order of magnitude, whereas $D_{84}$ is larger in the steepest soils by a factor of 4 (Fig. 8a). The fraction coarser than $10 \mathrm{~mm}$ increases from 2 to $11 \%$ with increasing slope from 0.38 to $0.83 \mathrm{~m} \mathrm{~m}^{-1}$, while the fraction coarser than $1 \mathrm{~mm}$ doubles, from around $25 \%$ to more than $50 \%$ of the sample (Fig. 8b).

\subsection{Sediment transported by rivers}

Sediment characteristics have been measured along the river in three basins: Adams Creek basin, Bean Creek basin and Bald Rock basin (Fig. 9). These basins have a drainage area of $10.1,14.7$ and $0.7 \mathrm{~km}^{2}$, respectively. First, we observe that most gravel bars show an armouring of the surface, with surface sediment coarser than subsurface sediment (squares and circles in Fig. 9, respectively). The Adams Creek basin exhibits the most prominent break in slope (Figs. 1, 5a and 9a). It is also the basin in which grain size changes the most dramatically across the main profile convexity: both surface and subsurface grain size $\left(D_{50}\right.$ and $\left.D_{84}\right)$ increase substantially downstream of the break in slope separating the plateau from the steepened landscape. In the Bean Creek basin, the landscape is generally steeper than in the Adams Creek basin and the transition from steepened landscape to upper catchment is more subdued (Figs. 1, 5a and 9b). Sediment tends to be coarser in this catchment than in the Adams Creek basin, except for the two lowermost sites, which have a GSD similar to the GSD at the two lowermost sites in the Adams Creek basin. Upstream of these two sites, data seem to show an overall downstream fining, with the uppermost site having the coarsest subsurface sediment in the entire Bean Creek basin. The Bald Rock Basin is the smallest of the three basins (Fig. 9c). Sediment in the channel is fine-grained compared to the basins discussed above, with $D_{50}$ and $D_{84}$ not exceeding 13 and $54 \mathrm{~mm}$, respectively. The data seem to show a slight downstream coarsening of the sediment, with the uppermost site showing the finest GSD and the lowermost site exhibiting the coarsest GSD (see GSD on right panel in Fig. 9c). The amount of sediment within this channel is low compared to the other studied basins, as demonstrated by substantial bedrock exposure in the channel, in particular downstream of the break in slope where no sediment was found.

As mentioned in Sect. 2.4, a power relationship between the grain size of the grains entrained by the river and $\omega_{m}^{\prime}$ would be expected: $D=k\left(\omega_{m}^{\prime}\right)^{b}$, with $k$ a constant and $b$ an exponent equal to $2 / 3$ in the case of uniform grain sizes (e.g. Bathurst, 2013). The whole data set collected in this study is noisy (Fig. 10), but it can be seen that sites with the higher flow competence tend to have the coarsest sediment and vice versa. In Adams Creek, where $\omega_{m}^{\prime}$ spans over 2 orders of magnitude, $D_{50}$ and $D_{84}$ data show a good agreement with a power relationship, demonstrating an increase in both flow competence and grain size past the main topographic break in slope (Table 1, Fig. 10). However, the maximum grain size $D_{100}$ is not as well correlated with $\omega_{m}^{\prime}$, in particular in the subsurface, in contradiction with theory, flume and field studies (Whitaker and Potts, 2007; Bathurst, 2013). The exponent $b$ tends to be higher for $D_{50}$ than for $D_{84}$, both for surface and subsurface samples. The range of $\omega_{m}^{\prime}$ in Bean Creek and Bald Rock basin is too small to produce meaningful regressions.

When considering the morphological divisions in the studied landscape, it is noticeable that steepened landscape sites have systematically higher flow competence than plateau 
(a)

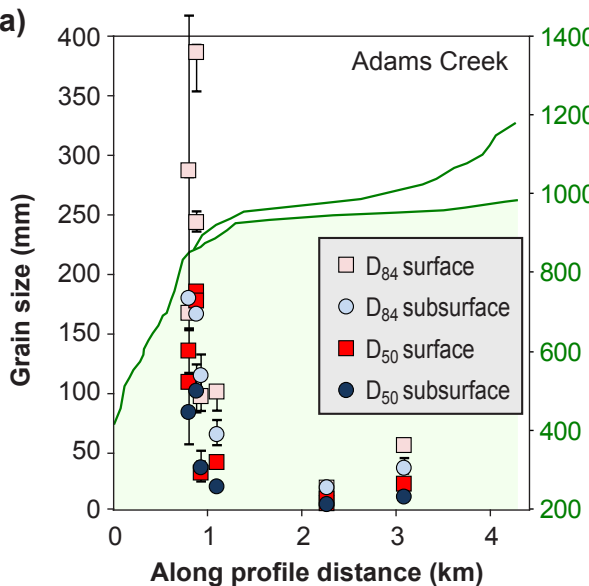

(b)

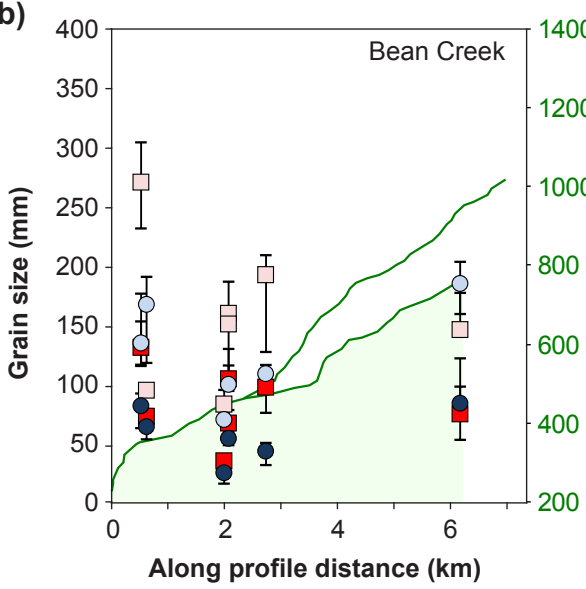

(c)

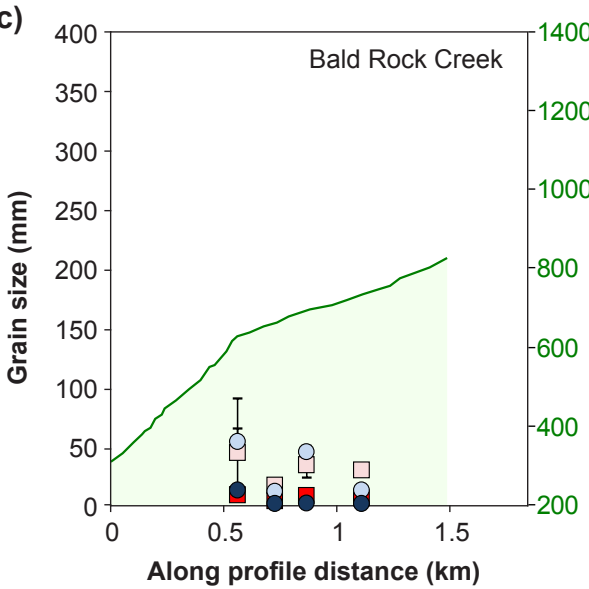

$\%$ mass finer than

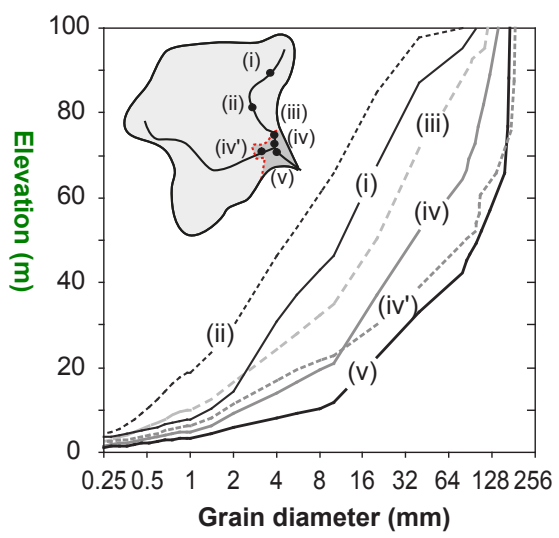

$\%$ mass finer than

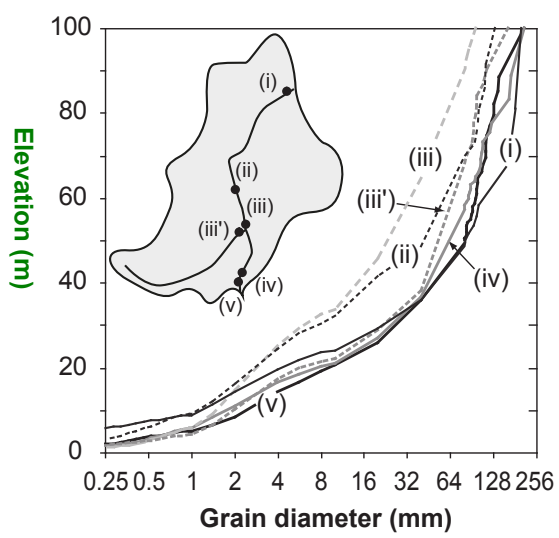

$\%$ mass finer than

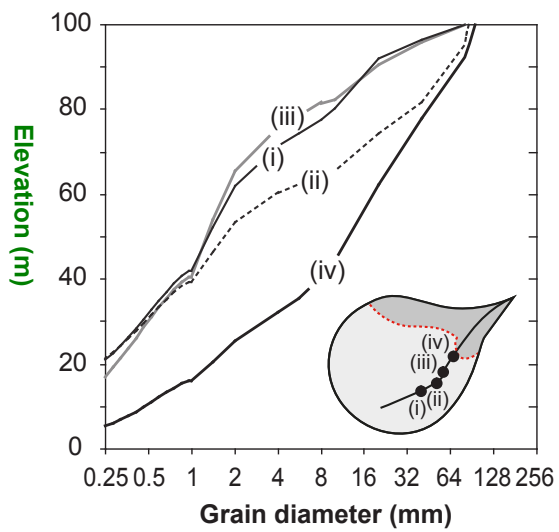

Figure 9. Grain size of the fluvial sediment along (a) Adams Creek, (b) Bean Creek and (c) Bald Rock Creek. Left panels: $D_{50}$ and $D_{84}$ measured along the rivers (subsurface and surface). Error bars represent plus or minus values calculated according to procedure described in Sect. 2.3. River profiles are shown in green; note change in scale on the $x$ axis. Right panels: cumulative grain size distribution of subsurface sediment (note the $\log _{2}$ scale on the $x$ axis). Inset grey shapes are schematic map representations of the basins showing the distribution of the samples - (i) being the site the further upstream; transition from plateau to steepened landscape is highlighted by shading and the red dotted line, except in Bean Creek, where there is no clear transition. 

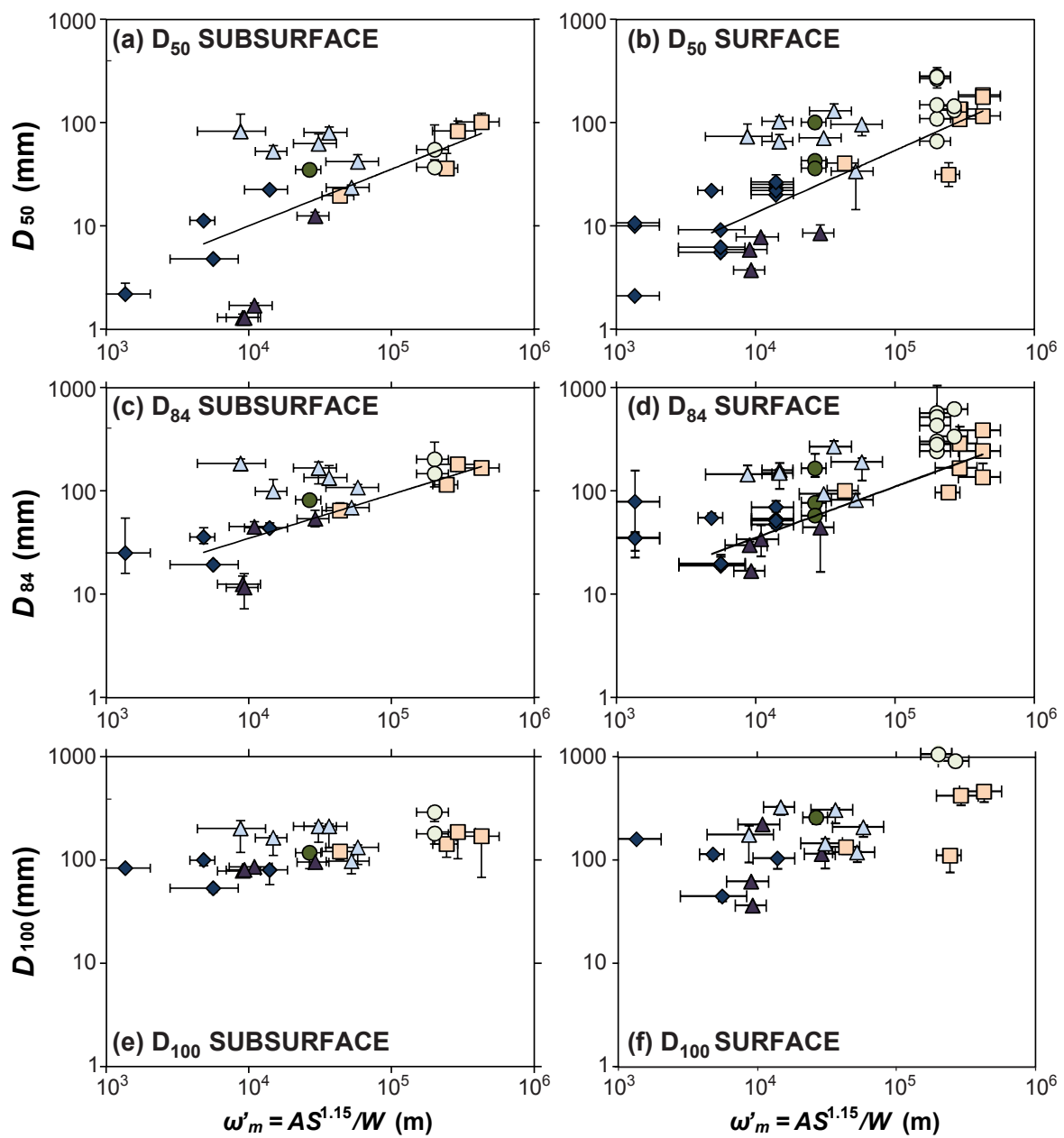

\begin{tabular}{|l|llr|}
\cline { 2 - 3 } \multicolumn{1}{l|}{ KEY: } & Plateau sites: $\diamond$ & Large basin: $\mathrm{O}$ & Small basin $\left(\mathrm{BRB}, 0.7 \mathrm{~km}^{2}\right): \Delta$ \\
\hline Steepened landscape sites: $\square$ & Large basin: $\mathrm{O}$ & & Bean Creek basin sites: $\Delta$ \\
\hline
\end{tabular}

Figure 10. Fluvial sediment grain size as a function of $\omega_{m}^{\prime}$. Grain sizes are shown for both subsurface (left panels) and surface (right panels): $D_{50}$ (top panels), $D_{84}$ (middle panels) and $D_{100}$ (bottom panels). Note the log-log scale. Vertical error bars represent plus or minus values calculated according to procedure described in Sect. 2.3. Horizontal bars reflect variability of channel width at the scale of the $100 \mathrm{~m}$ reaches considered (Sect. 2.3). We classify sites based on their position with respect to the topographic break in slope (see key and Fig. 5); Bean Creek sites are treated separately due to the lack of a clear morphological distinction between relict surface and steepened landscape. Lines in (a) to (d) represent best-fit power regression for Adams Creek sites (Table 1) and are shown as a reference for comparison with other sites.

sites (Fig. 10). Importantly, plateau sites tend to have smaller grain sizes than steepened landscape sites; this is exemplified by the subsurface samples which have not experienced armouring and are therefore more likely to be representative of the sediment transported by the river (Fig. 10): $D_{50}, D_{84}$ and $D_{100}$ on the plateau do not exceed 35,82 and $118 \mathrm{~mm}$, respectively; in the steepened landscape, $D_{50}, D_{84}$ and $D_{100}$ are in the ranges $20-101,65-202$ and $120-290 \mathrm{~mm}$, respectively. These observations stand irrespective of basin size: the plateau site in the large Cascade Creek basin (solid circles in Fig. 10) has the highest $\omega_{m}^{\prime}$ and the coarsest sediment of all plateau sites but lower $\omega_{m}^{\prime}$ and finer sediment than the steepened landscape sites. Similarly, the data points from the sites along the incised Little North Fork River (open circles in Fig. 10) fall within the grain size and $\omega_{m}^{\prime}$ domains delineated by the steepened landscape data points. The Bean Creek sites sit at an intermediate position between the steepened landscape and plateau sites in terms of flow competence but share the range of grain size with steepened landscape sites. 


\section{Discussion}

\subsection{Landscape steepness and the characteristics of the sources of sediment}

Our results indicate that hillslope steepness partly controls the grain size of the sediment supplied to rivers by controlling the type of process by which sediment is supplied (Figs. 7 and 8). Slope failures and scree cones are observed on slopes steeper than $0.7 \mathrm{~m} \mathrm{~m}^{-1}$. They provide much coarser sediment to river systems than the erosion of soils does. Within soils, grain size seems to generally increase with increasing slope steepness (Figs. 7 and 8).

The hillslope relief in a landscape is related to both erosion rate and the efficiency of sediment transport processes (e.g. Roering et al., 2007). The soils we sampled developed on a similar parent material and have been subjected to a similar climate with similar vegetation (Chaparral, Oak, Pine). Our samples are only separated by several hundred metres laterally and less than $150 \mathrm{~m}$ vertically. We thus assume that sediment transport efficiency is similar at all of these sites. Consequently, differences in hillslope relief or mean hillslope gradient $S_{\mathrm{h}}$ (the ratio of hillslope relief over the horizontal length of the hillslope) in our field area should be driven by differences in erosion rates (Roering et al., 2007; Hurst et al., 2012). These quantities can serve as a proxy for erosion rates as long as slope gradients remain gentler than a threshold slope beyond which landsliding processes begin to dominate; this threshold slope typically varies between 0.8 and $1.2 \mathrm{~m} \mathrm{~m}^{-1}$ (e.g. Roering et al., 1999; Binnie et al., 2007; DiBiase et al., 2010; Matsushi and Matsuzaki, 2010) and was estimated $\sim 0.8 \mathrm{~m} \mathrm{~m}^{-1}$ in the study area (Hurst et al., 2012). In the Bald Rock basin we see that both $D_{50}$ and $D_{84}$ seem to generally increase with increasing $S_{\mathrm{h}}$ (Fig. 8) and therefore with erosion rate (Hurst et al., 2012). It is notable that sediment flux is directly related to erosion rates: a doubling of erosion rate should lead to a doubling of sediment flux to the river. An increase in erosion rate and hillslope steepness will therefore result in rivers being supplied with larger amounts of coarser sediment, making an increase in erosion rate more likely to influence fluvial sediment GSD than a simple change in source GSD.

Erosion rates and soil thicknesses combine to control how long particles spend in the soil (e.g. Small et al., 1999; Mudd and Furbish, 2006; Brantley and White, 2009; Mudd and Yoo, 2010; Yoo et al., 2011). A greater time spent in the soil gives particles longer exposure to processes that can reduce grain sizes, such as exposure to salt weathering (e.g. Wells et al., 2008), fracturing of rock due to root growth and tree throw (e.g. Gabet and Mudd, 2010; Roering et al., 2010), and/or clay and secondary mineral formation due to chemical weathering (e.g. Yoo and Mudd, 2008; Maher, 2010; Sweeney et al., 2012). We infer that the time particles spend within the weathering zone is significantly shorter in the steeper transects, giving chemical weathering processes less time to weaken parent material and resulting in coarser sediment. It can be seen in the fraction finer than $10 \mathrm{~mm}$ that the lower the mean hillslope gradient (and thus, we infer, the lower the erosion rate), the higher the clay and silt content and the lower the content in the fraction 1-10 mm (Fig. 7b). The particle size distributions for this fraction tend to be bimodal, exhibiting a low at $0.5-1 \mathrm{~mm}$; this is consistent with previous observations that rocks which weather to sand (e.g. granite, sandstone) will produce a distinct bimodal distribution compared to rocks which weather to clays (Wolcott, 1988; Marshall and Sklar, 2012).

One metric to describe how long particles remain in the soil is the turnover time, which is the ratio of soil thickness to erosion rate multiplied by the ratio of soil density to rock density (Almond et al., 2007; Mudd and Yoo, 2010). In a steadily eroding soil, the turnover time is equivalent to the mean residence time of the particles (Mudd and Yoo, 2010). We quantified turnover time in the two "equilibrated" transects above and below the break in slope (POMD and BRC, respectively; Figs. 2 and 3). In our study area, erosion rates can be estimated as a function of hilltop curvature (Hurst et al., 2012): we calculate erosion rates of 0.06 and $0.1 \mathrm{~mm} \mathrm{ka}^{-1}$ for POMD and BRC, respectively. Soil thickness is $0.51 \pm 0.09 \mathrm{~m}$ and $0.45 \pm 0.12 \mathrm{~m}$ for POMD and BRC, respectively (Yoo et al., 2011). Assuming a soil to rock density ratio of $1 / 2$, a ratio common in granitic landscapes (Heimsath et al., 2001; Riggins et al., 2011), we calculate a turnover time of $\sim 4.3$ and $2.3 \mathrm{ka}$ for the plateau and steepened landscape transects, respectively, showing that landscape steepening causes a halving of the turnover time in our study area.

Geochemical analysis of these soils shows that chemical weathering is most pronounced in the plateau transect POMD $\left(S_{\mathrm{h}}=0.38 \mathrm{~m} \mathrm{~m}^{-1}\right.$, Figs. 2 and 3$)$; it has the highest pedogenic crystalline iron oxide concentrations and is also the most enriched in $\mathrm{Zr}$ and $\mathrm{Ti}$, indicating a greater extent of chemical weathering (Yoo et al., 2011). Thus the difference in grain size amongst the hillslope samples can be at least partially explained through a chemical weathering mechanism: weathering of primary silicate minerals results in clay production and so one would expect more chemically weathered soils to be enriched in clays, as is the case in our field area (Fig. 7). Chemical weathering does not break up coarse clasts directly, but it can make clasts more susceptible to physical breakdown by weakening the clasts. We found that in the steep FTA, BRC and BRB transects $\left(S_{\mathrm{h}}=0.67-\right.$ $0.84 \mathrm{~m} \mathrm{~m}^{-1}$, Fig. 3), coarse clasts appeared to be nearly pristine in terms of chemical weathering: there was little iron oxide staining, and these clasts would ring when hit with a rock hammer (Fig. 4a). Clasts within the POMD transect tended to be stained with iron oxide (as supported by increased pedogenic crystalline Fe content; Yoo et al., 2011) and could be easily broken with a rock hammer. While these are admittedly qualitative observations, they are supported by the geo- 
chemical data which show enhanced weathering in POMD relative to FTA, BRC and BRB (Yoo et al., 2011).

\subsection{Landscape steepness and fluvial sediment GSD in mountainous landscapes}

Our data show that fluvial sediment grain size seems to generally increase with increasing flow competence (Fig. 10). The data are noisy but the trends are significant in the Adams Creek basin, where there is a clear increase in both flow competence and sediment grain size over the prominent break in slope that separates the steepened landscape from the relict topography (Table 1, Figs. 9a and 10). The exponents in the power relationship between grain size and $\omega_{m}^{\prime}$ are lower than the value of $2 / 3$ expected from theory and flume experiments with uniform grain size (Table 1), which may reflect significant hiding/exposure effects in sediment composed of such a wide range of grain sizes (up to boulder size) (Whitaker and Potts, 2007; Bathurst, 2013). The exponent on $D_{50}$ tends to be higher than on $D_{84}$, indicating that the bulk of the sediment coarsens faster than the coarse tail of the distribution, though the exponents are not statistically discernible (Table 1). Depletion in fines could result in sediment coarsening, but it cannot be the sole cause for coarsening in our case: the plateau sites would still be significantly finer than the steepened landscape sites in Adams Creek even after complete removal of their fraction finer than 1, 2 or even $10 \mathrm{~mm}$ (Fig. 9a).

In a situation where all grain sizes are available for fluvial transport, increasing flow competence should lead to an increase in grain size through selective entrainment of larger grains. In our study area, field observations and inspection of the $1 \mathrm{~m}$ resolution lidar data suggest that a change in sediment source is also responsible for the increase in fluvial sediment grain size. On the plateau, hillslope gradient rarely exceeds $0.7 \mathrm{~m} \mathrm{~m}^{-1}$; hillslopes are soil-mantled and we find no evidence of landslides. In addition, we find no coarse sediment available for transport along the studied rivers on the plateau: clasts larger than cobble size are very rare on the plateau, whereas boulders are widespread on the steepened landscape (e.g. see $D_{100}$ data in Fig. 10 and Table A2). This suggests that the fine-grained nature of the fluvial sediment on the plateau is primarily due to the scarcity of coarse sediment supply (Fig. 11a). Below the break in slope, landslides, scree cones and debris flows supply coarse sediment to the channels: evidence of reworked debris-flow deposits and selective mobilisation of sediment emplaced by mass wasting processes is widespread along the rivers below the break in slope (Fig. 11b). We therefore interpret the increase in sediment coarseness from the plateau to the steepened landscape as a result of an increase in both flow competence and the size of the sediment supplied from hillslopes to the channels. This observation is consistent with previous studies in tectonically or climatically perturbed landscapes. Whittaker et al. (2010) showed that the grain size of fluvial sediment along rivers in the Apennines increases at the transition from low-relief
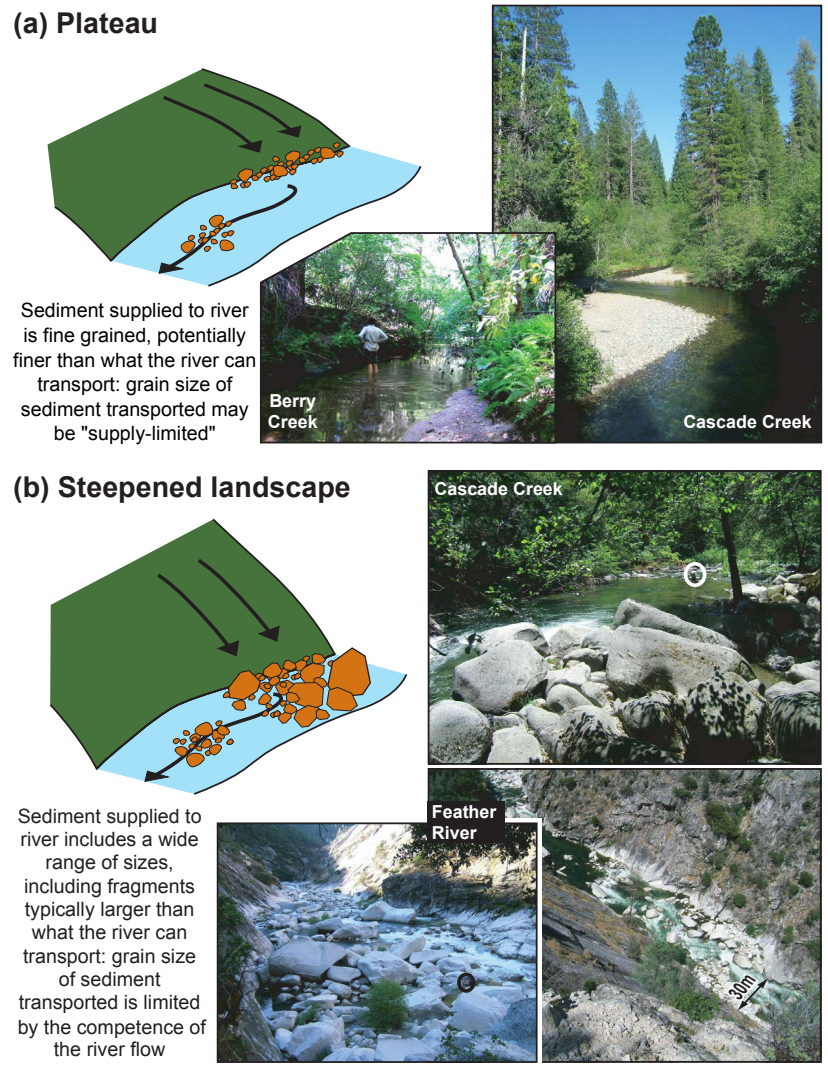

Figure 11. Diagrams and photographs illustrating the contrast in sediment dynamics between sites on the plateau and sites across the steepened landscape. (a) On the plateau, rivers are fed with soil material and there is a clear lack of coarse material, even along large rivers; the drainage area of Cascade Creek where the photo was taken is $58 \mathrm{~km}^{2}$ and the largest pebble found in the area has a $b$ axis of $260 \mathrm{~mm}$. (b) Along the steepened reaches of the rivers and in the gorges, a wide range of grain size is available and "lag" deposits are widespread, that is, concentrations of very large clasts resulting from the reworking by fluvial processes of material deposited by mass wasting processes. The very large boulders are up to $10 \mathrm{~m}$ in size and are very unlikely to be mobilised by fluvial processes. Photographs show evidence of reworking of debris-flow deposits near the confluence of Cascade Creek with the Feather River (top panels), selective mobilisation of sediment supplied by landslides, and rock falls below Bald Rock Dome in the Feather River (bottom panels). Standing people are circled on the photographs for scale.

soil-mantled landscape to steep high-relief landslide-prone landscape (see also Whittaker et al., 2007; Attal et al., 2011). Attal and Lavé (2006) also showed that fluvial sediment grain size along the Marsyandi River (Himalayas) increases at the transition from previously glaciated till-covered landscape to steep high-relief landslide-prone landscape; Attal and Lavé's (2006) measurements further indicated that till was a source of finer sediment to the rivers than landslides.

Two basins depart noticeably from the general trend (Fig. 10). The Bald Rock basin sites (solid triangles in 
Fig. 10) may represent a situation where the grain size of the fluvial sediment is, at least temporarily, limited by sediment supply. In this small basin $\left(0.7 \mathrm{~km}^{2}\right)$, fluvial sediment is fine-grained and scarce, with $D_{50}$ and $D_{84}$ not exceeding 13 and $54 \mathrm{~mm}$, respectively (Fig. 9c). The channel has abundant bedrock exposure; no sediment was found in the channel downstream of the break in slope. We interpret this situation as resulting from a shortage of sediment in the channel. The basin is soil-mantled and entirely vegetated, and we found no evidence of recent slope failure within the basin, even below the break in slope. This may represent a transient situation where the material supplied to the channel has been completely evacuated from the basin; sediment will be replenished in the channel when sediment flux from hillslopes is at least temporarily - substantially increased, e.g. following forest fires (Gabet, 2003; Lamb et al., 2011, 2013; DiBiase and Lamb, 2013; Riley et al., 2013).

The Bean Creek basin appears to have undergone a different type of response compared to the other basins. It exhibits no obvious topographic break in slope delimiting the plateau from the steepened landscape (Figs. 1, 5a and 9b). The whole basin is steeper than the plateau basins but less steep than the steepened landscape in adjacent basins. It is steep enough to experience landslides and debris flows, both processes supplying coarse sediment to the river, as observed in the field. Flow competence at the Bean Creek sites tends to be higher than at the plateau sites and lower than at the steepened landscape sites (Fig. 10). Fluvial sediment grain size in Bean Creek is coarser than at the plateau sites and within the range of values measured at the steepened landscape sites, testifying again to the influence of source type on fluvial sediment GSD (Fig. 10).

A series of observations suggest a rapid response of the hillslopes (in terms of source characteristics) to river steepening. Firstly, we observe that, only a few hundreds of metres downstream of the main topographic break in slope, fluvial sediment is significantly coarser than on the plateau and includes boulders that are typically absent on the plateau, as exemplified by the Adams Creek data (Fig. 9a). As rivers steepen and increase their competence in response to the increase in incision rate along the main stem of the Feather River, the adjacent hillslopes must steepen and respond rapidly to provide rivers with coarse sediment. Secondly, we note the absence of inner gorges in the steepened landscape, suggesting a tight coupling between the channel and hillslopes and a rapid response of hillslopes to an increase in the rate of river downcutting. These observations are consistent with the topographic analysis of Hurst et al. (2012) in the study area, which suggests that the response time of hillslopes in this landscape is rapid relative to that of the stream network. This rapid response means that the increase in flow competence and change in sediment sources occur at a similar location along the rivers, making isolating the relative influences of these two controls on the grain size of the sediment transported by the rivers challenging.

\section{Conclusions}

We have quantified the grain size distribution of sediment in both source areas (hillslope soils and landslide deposits) and channels in a mountainous landscape where the underlying lithology is exclusively tonalite and where erosion rates vary over an order of magnitude (Riebe et al., 2000; Hurst et al., 2012). We find that the coarseness of hillslope sediment increases with increasing mean hillslope gradient (where mean hillslope gradient represents the ratio of hillslope relief over the horizontal length of the hillslope) and erosion rate. We hypothesise that, in our soil samples, this is due to a decrease in residence time of rock fragments, causing particles to be exposed for shorter periods of time to processes that can reduce grain sizes, such as exposure to salt weathering, fracturing of rock due to root growth and tree throw, and/or clay formation due to chemical weathering. For slopes in excess of $0.7 \mathrm{~m} \mathrm{~m}^{-1}$, mass wasting processes (e.g. landsliding) and scree cones supply much coarser sediment to rivers, with $D_{50}$ and $D_{84}$ more than 1 order of magnitude larger than in soils. Rapidly eroding landscapes also contribute more sediment to rivers than slowly eroding slopes per unit area; thus for basins of equal size a rapidly eroding basin will contribute a much larger amount of coarse sediment to the river network than a slowly eroding basin.

Changes in grain size and sediment fluxes from hillslopes are shown to impact the grain size of the sediment transported by the rivers. Fluvial sediment in the tributary basins hanging above the rapidly incising Feather River exhibits a significant downstream coarsening. The locus of the increase in grain size coincides with the prominent break in slope that developed along the river profiles in response to an increase in incision rate along the main stem of the Feather River. This increase in grain size is caused by an increase in flow competence (mostly driven by channel steepening) as well as a change in sediment source and in sediment dynamics: on the plateau upstream of the break in slope, rivers transport easily mobilised fine-grained sediment derived exclusively from soils. Downstream of the break in slope, mass wasting processes supply a wide range of grain sizes (up to bus-sized boulders) that rivers entrain selectively, depending on the competence of their flow. The absence of evidence, below the break in slope, of river reaches where the grain size of the fluvial sediment is limited by the grain size of the sediment supplied from hillslopes suggests that the response time of hillslopes to an increase in the rate of base-level lowering is rapid relative to that of the stream network in this landscape.

\section{Data availability}

Cumulative grain size distributions for all volumetric samples are available in two Excel spreadsheets in the supplementary material. The spreadsheet "Data_SoilLandslidesGSD_FeatherRiver_Attal2015" con- 
tains the grain size distributions of the 11 hillslope sites (one sheet per site): 8 in soils and 3 in landslides. The spreadsheet "Data_RiverSedimentGSD_FeatherRiver_Attal2015" contains the grain size distributions of the 21 fluvial sediment sites (one sheet per site). 
Appendix A: Tables with description of sites and data

Table A1. Description of hillslope sites data. $D_{100}$ is maximum grain size. Plus or minus values are calculated according to procedure described in Sect. 2.3.

\begin{tabular}{|c|c|c|c|c|c|c|c|c|c|c|c|c|c|c|}
\hline \multirow[t]{2}{*}{ Site ID } & \multicolumn{3}{|c|}{$D_{50}(\mathrm{~mm})$} & \multicolumn{3}{|c|}{$D_{84}(\mathrm{~mm})$} & \multirow{2}{*}{$\begin{array}{l}D_{100} \\
(\mathrm{~mm})\end{array}$} & \multirow{2}{*}{$\begin{array}{r}\text { Total } \\
\text { sample } \\
\text { mass } \\
(\mathrm{kg})\end{array}$} & \multirow{2}{*}{$\begin{array}{r}\% \text { mass } \\
\text { largest } \\
\text { clast }\end{array}$} & \multirow{2}{*}{\multicolumn{2}{|c|}{$\begin{array}{c}\% \text { mass } \\
\text { coarser } \\
\text { than } \\
1 \mathrm{~mm}\end{array}$}} & \multirow{2}{*}{\multicolumn{2}{|c|}{$\begin{array}{c}\% \text { mass } \\
\text { coarser } \\
\text { than } \\
10 \mathrm{~mm}\end{array}$}} & \multirow{2}{*}{$\begin{array}{c}\text { Mean } \\
\text { hillslope } \\
\text { gradient } \\
S_{h}\left(\mathrm{~m} \mathrm{~m}^{-1}\right)\end{array}$} \\
\hline & & - & + & & - & + & & & & & & & & \\
\hline \multicolumn{15}{|c|}{ Soils } \\
\hline POMD2 & 0.12 & $<0.01$ & $<0.01$ & 1.25 & $<0.01$ & $<0.01$ & 58.3 & 227.0 & $0.1 \%$ & 21 & $<0.5$ & 1 & $<0.5$ & 0.38 \\
\hline POMD4 & 0.11 & $<0.01$ & $<0.01$ & 1.30 & $<0.01$ & $<0.01$ & 63.4 & 163.3 & $0.2 \%$ & 22 & $<0.5$ & 1 & $<0.5$ & 0.38 \\
\hline POMD6 & 0.10 & $<0.01$ & $<0.01$ & 1.65 & $<0.01$ & $<0.01$ & 40.0 & 550.4 & $0.02 \%$ & 29 & $<0.5$ & 2 & $<0.5$ & 0.38 \\
\hline FTA1 & 0.34 & $<0.01$ & $<0.01$ & 1.92 & $<0.01$ & $<0.01$ & 26.9 & 122.3 & $0.02 \%$ & 32 & $<0.5$ & 1 & $<0.5$ & 0.67 \\
\hline FTA9 & 0.36 & 0.11 & 0.12 & 3.55 & 1.43 & 109.20 & 220.0 & 173.0 & $8.5 \%$ & 39 & 6 & 12 & 9 & 0.67 \\
\hline BRC3 & 0.47 & 0.04 & 0.04 & 4.79 & 0.65 & 0.76 & 148.8 & 211.7 & $2.2 \%$ & 43 & 1 & 8 & 2 & 0.76 \\
\hline $\mathrm{BRC} 0$ & 0.22 & $<0.01$ & $<0.01$ & 2.00 & $<0.01$ & $<0.01$ & 79.1 & 189.0 & $0.4 \%$ & 31 & $<0.5$ & 2 & $<0.5$ & 0.76 \\
\hline BRB8-9h & 1.15 & $<0.01$ & $<0.01$ & 7.02 & $<0.01$ & $<0.01$ & 77.3 & 63.8 & $1.0 \%$ & 53 & $<0.5$ & 11 & $<0.5$ & 0.83 \\
\hline \multicolumn{15}{|c|}{ Landslides } \\
\hline LD1 & 34.95 & 7.62 & 9.86 & 148.35 & 28.98 & 23.97 & 176.8 & 84.8 & $9.0 \%$ & 82 & 2 & 69 & 3 & 0.84 \\
\hline LD2 & 66.16 & 8.56 & 10.79 & 138.57 & 30.73 & 9.34 & 189.2 & 113.3 & $8.3 \%$ & 87 & 1 & 78 & 2 & 0.89 \\
\hline LD3 & 46.41 & 18.21 & 20.18 & 133.01 & 45.48 & 68.29 & 207.2 & 81.4 & $15.2 \%$ & 82 & 3 & 67 & 6 & 0.74 \\
\hline
\end{tabular}




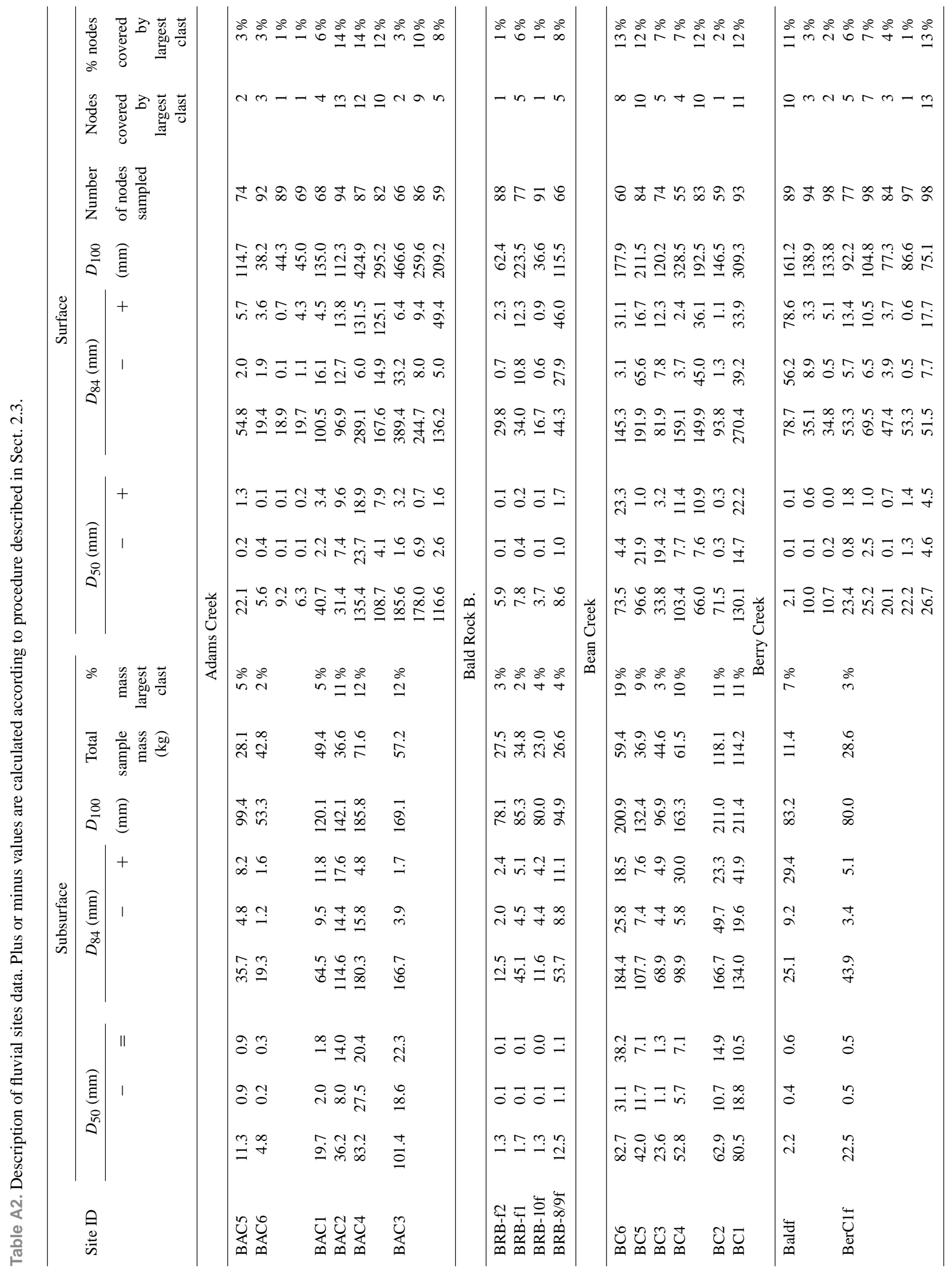




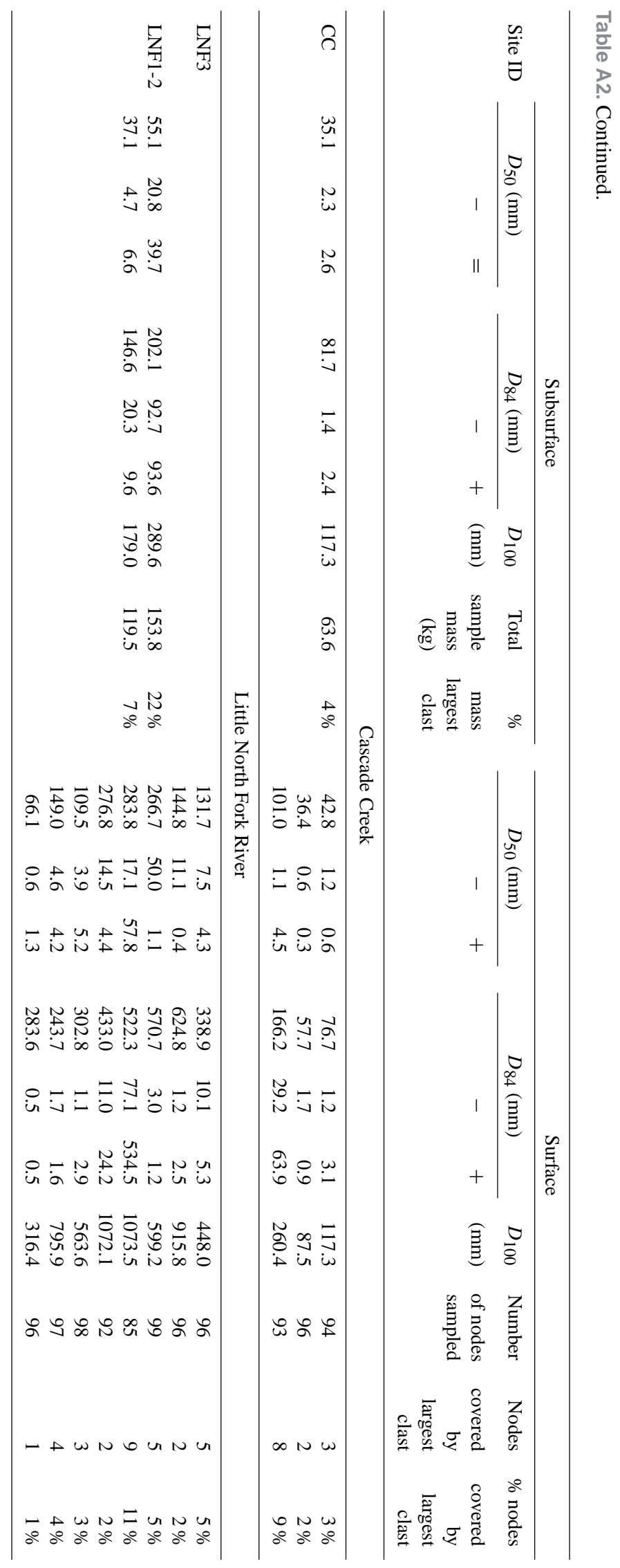


Table A3. Location and description of fluvial sites. Coordinates are in the UTM reference system (WGS1984). For each river, sites are ordered downstream (asterisk indicates sites on tributaries). Drainage area and channel slope (calculated over $100 \mathrm{~m}$ ) were extracted from the $1 \mathrm{~m}$ resolution lidar-derived DEM, except for the Cascade Creek and lowermost Berry Creek sites, where the $10 \mathrm{~m}$ resolution USGS DEM data were used instead. Minimum and maximum channel widths were measured over a $100 \mathrm{~m}$ long stretch on lidar-derived DEM complemented with Google Maps images; mean width is given, with \pm representing the difference between mean and extrema.

\begin{tabular}{|c|c|c|c|c|c|c|}
\hline Site ID & $\begin{array}{c}\text { Easting } \\
\text { (m) }\end{array}$ & $\begin{array}{l}\text { Northing } \\
\text { (m) }\end{array}$ & $\begin{array}{l}\text { Elevation } \\
\text { (m) }\end{array}$ & $\begin{array}{r}\text { Drainage } \\
\text { area } \\
\left(\mathrm{km}^{2}\right)\end{array}$ & $\begin{array}{c}\text { Slope } \\
\left(\mathrm{m} \mathrm{m}^{-1}\right)\end{array}$ & $\begin{array}{l}\text { Width } \\
\text { (m) }\end{array}$ \\
\hline \multicolumn{7}{|c|}{ Adams Creek } \\
\hline BAC5 & 644550 & 4394120 & 1012 & 0.63 & 0.032 & $2.5 \pm 0.5$ \\
\hline BAC6 & 644460 & 4393420 & 970 & 1.39 & 0.028 & $4 \pm 2$ \\
\hline $\mathrm{BAC} 1$ & 644870 & 4392860 & 918 & 2.02 & 0.118 & $4 \pm 1$ \\
\hline $\mathrm{BAC} 2$ & 644840 & 4392720 & 887 & 2.07 & 0.345 & $2.5 \pm 0.5$ \\
\hline BAC4* & 644880 & 4392640 & 849 & 7.79 & 0.149 & $3 \pm 1$ \\
\hline BAC3 & 644910 & 4392640 & 843 & 9.87 & 0.169 & $3 \pm 1$ \\
\hline \multicolumn{7}{|c|}{ Bald Rock Basin } \\
\hline BRB-f2 & 645245 & 4389820 & 739 & 0.17 & 0.206 & $3 \pm 1$ \\
\hline BRB-f1 & 645420 & 4389900 & 703 & 0.32 & 0.136 & $3 \pm 1$ \\
\hline BRB-10f & 645485 & 4389940 & 692 & 0.37 & 0.134 & $4 \pm 1$ \\
\hline BRB-8/9f & 645575 & 4390100 & 643 & 0.52 & 0.271 & $4 \pm 1$ \\
\hline \multicolumn{7}{|c|}{ Bean Creek } \\
\hline BC6 & 644500 & 4390200 & 947 & 0.15 & 0.154 & $2 \pm 1$ \\
\hline BC5 & 643405 & 4387800 & 492 & 5.81 & 0.074 & $5 \pm 2$ \\
\hline $\mathrm{BC} 3$ & 643535 & 4387220 & 454 & 10.04 & 0.038 & $4.5 \pm 1.5$ \\
\hline $\mathrm{BC} 4^{*}$ & 643500 & 4387200 & 456 & 3.15 & 0.032 & $4 \pm 1$ \\
\hline $\mathrm{BC} 2$ & 643425 & 4386220 & 362 & 14.23 & 0.023 & $6 \pm 2$ \\
\hline $\mathrm{BC} 1$ & 643400 & 4386140 & 360 & 14.33 & 0.026 & $6 \pm 2$ \\
\hline \multicolumn{7}{|c|}{ Berry Creek } \\
\hline Baldf & 642215 & 4389860 & 946 & 0.04 & 0.096 & $2 \pm 1$ \\
\hline BerC1f & 637324 & 4389271 & 610 & 23.16 & 0.006 & $4.5 \pm 1.5$ \\
\hline \multicolumn{7}{|c|}{ Cascade Creek } \\
\hline $\mathrm{CC}$ & 654814 & 4397091 & 1119 & 58.42 & 0.011 & $12.5 \pm 2.5$ \\
\hline \multicolumn{7}{|c|}{ Little North Fork River } \\
\hline LNF3 & 647534 & 4400281 & 839 & 104.13 & 0.075 & $20 \pm 5$ \\
\hline LNF1-2 & 648124 & 4396981 & 492 & 119.21 & 0.052 & $20 \pm 5$ \\
\hline
\end{tabular}




\section{The Supplement related to this article is available online at doi:10.5194/esurf-3-201-2015-supplement.}

Acknowledgements. This work was funded by the Carnegie Trust for the Universities of Scotland (grant awarded to M. Attal), the US National Science Foundation (grant EAR0819064 awarded to K. Yoo and S. Mudd) and the UK Natural Environment Research Council (grant NE/H001174/1 awarded to S. Mudd). We are extremely grateful to K. Maher and K. Mayer for sample handling and valuable assistance in the field. We would like to thank L. Sklar and J. Marshall for stimulating discussions and for allowing us to use some equipment in their sedimentology lab. We thank the four anonymous reviewers (including two reviewers of an earlier version of the manuscript that had been submitted to another journal) as well as the associate editor J. West for their very helpful and constructive comments, which allowed us to greatly improve the manuscript. We thank H. Parsons and M. Johnston for help collecting the landslide data.

Edited by: A. J. West

\section{References}

Almond, P., Roering, J., and Hales, T. C.: Using soil residence time to delineate spatial and temporal patterns of transient landscape response, J. Geophys. Res., 112, F03S17, doi:10.1029/2006JF000568, 2007.

Armitage, J. J., Duller, R. A., Whittaker, A. C., and Allen, P. A.: Transformation of tectonic and climatic signals from source to sedimentary archive, Nat. Geosci., 4, 231-235, doi:10.1038/ngeo1087, 2011.

Attal, M. and Lavé, J.: Changes of bedload characteristics along the Marsyandi River (central Nepal): Implications for understanding hillslope sediment supply, sediment load evolution along fluvial networks, and denudation in active orogenic belts, Geological Society of America Special Paper 398, Geological Society of America, Boulder, Colorado, 143-171, doi:10.1130/2006.2398(09), 2006.

Attal, M., Tucker, G. E., Whittaker, A. C., Cowie, P. A., and Roberts, G. P.: Modeling fluvial incision and transient landscape evolution: Influence of dynamic channel adjustment, J. Geophys. Res., 113, F03013, doi:10.1029/2007JF000893, 2008.

Attal, M., Cowie, P. A., Whittaker, A. C., Hobley, D., Tucker, G. E., and Roberts, G. P.: Testing fluvial erosion models using the transient response of bedrock rivers to tectonic forcing in the Apennines, Italy, J. Geophys. Res., 116, F02005, doi:10.1029/2010JF001875, 2011.

Bathurst, J. C., Graf, W. H., and Cao, H. H.: Bed load discharge equations for steep mountain rivers, in: Sediment Transport in Gravel-bed Rivers, edited by: Thorne, C. R., Bathurst, J. C., and Hey, R. D., John Wiley, Chichester, UK, 453-477, 1987.

Bathurst, J. C.: Critical conditions for particle motion in coarse bed materials of nonuniform size distribution, Geomorphology, 197, 170-184, doi:10.1016/j.geomorph.2013.05.008, 2013.

Bennett, G. L., Molnar, P., McArdell, B. W., and Burlando, P.: A probabilistic sediment cascade model of sediment transfer in the Illgraben, Water Resour. Res., 50, doi:10.1002/2013WR013806, 2014.
Bierman, P. and Steig, E. J.: Estimating rates of denudation using cosmogenic isotope abundances in sediment, Earth Surf. Proc. Land., 21, 125-139, doi:10.1002/(SICI)10969837(199602)21:2<125::AID-ESP511>3.0.CO;2-8, 1996.

Binnie, S. A., Phillips, W. M., Summerfield, M. A., and Fifield, L. K.: Tectonic uplift, threshold hillslopes, and denudation rates in a developing mountain range, Geology, 35, 743-746, 2007.

Brantley, S. L. and White, A. F.: Approaches to Modeling Weathered Regolith in Thermodynamics and Kinetics of Water-Rock Interaction, edited by: Oelkers, E. H. and Schott, J., Rev. Mineral. Geochem., 70, 435-484, 2009.

Brown, E. T., Stallard, R. F., Larsen, M. C., Raisbeck, G. M., and Yiou, F.: Denudation rates determined from the accumulation of in situ-produced ${ }^{10} \mathrm{Be}$ in the Luquillo experimental forest, Puerto Rico, Earth Planet. Sc. Lett., 129, 193-202, doi:10.1016/0012821X(94)00249-X, 1995.

Buffington, J. M. and Montgomery, D. R.: A systematic analysis of eight decades of incipient motion studies, with special reference to gravel-bedded rivers, Water Resour. Res., 33, 1993-2029, 1997.

Bunte, K. and Abt, S. R.: Sampling surface and subsurface particlesize distributions in wadable gravel-and cobble-bed streams for analyses in sediment transport, hydraulics, and streambed monitoring, Gen. Tech. Rep. RMRS-GTR-74, US Department of Agriculture, Forest Service, Rocky Mountain Research Station, Fort Collins, CO, p. 428, 2001.

Burbank, D. W, Leland, J., Fielding, E., Anderson, R. S., Brozovic, N., Reid, M. R., and Duncan, C.: Bedrock incision, rock uplift and threshold hillslopes in the northwestern Himalayas, Nature, 379, 505-510, 1996.

Casagli, N., Ermini, L., and Rosati, G.: Determining grain size distribution of the material composing landslide dams in the Northern Apennines: sampling and processing methods, Eng. Geol., 69, 83-97, doi:10.1016/S0013-7952(02)00249-1, 2003.

Chatanantavet, P., Lajeunesse, E., Parker, G., Malverti, L., and Meunier, P.: Physically based model of downstream fining in bedrock streams with lateral input, Water Resour. Res., 46, W02518, doi:10.1029/2008WR007208, 2010.

Church, M., McLean, D. G., and Walcott, J. F.: River bed gravels: sampling and analysis, in: Sediment Transport in Gravel-Bed Rivers, edited by: Thorne, C. R., Bathurst, J. C., and Hey, R. D., John Wiley and Sons, Chichester, 43-88, 1987.

Cowie, P. A., Whittaker, A. C., Attal, M., Roberts, G. P., Tucker, G. E., and Ganas, A.: New constraints on sediment-flux-dependent river incision: Implications for extracting tectonic signals from river profiles, Geology, 36, 535-538, doi:10.1130/G24681A.1, 2008.

Crosby, B. T. and Whipple, K. X.: Knickpoint initiation and distribution within fluvial networks: 236 waterfalls in the Waipaoa River, North Island, New Zealand, Geomorphology, 82, 16-38, doi:10.1016/j.geomorph.2005.08.023, 2006.

DiBiase, R. A. and Lamb, M. P.: Vegetation and wildfire controls on sediment yield in bedrock landscapes, Geophys. Res. Lett., 40, 1093-1097, doi:10.1002/grl.50277, 2013.

DiBiase, R. A., Whipple, K. X., Heimsath, A. M., and Ouimet, W. B.: Landscape form and millennial erosion rates in the San Gabriel Mountains, CA, Earth Planet. Sc. Lett., 289, 134-144, doi:10.1016/j.eps1.2009.10.036, 2010. 
Duller, R. A., Whittaker, A. C., Fedele, J. J., Whitchurch, A. L., Springett, J., Smithells, R., Fordyce, S., and Allen, P. A.: From grain size to tectonics, J. Geophys. Res., 115, F03022, doi:10.1029/2009JF001495, 2010.

Gabet, E. J.: Post-fire thin debris flows: field observations of sediment transport and numerical modeling, Earth Surf. Proc. Land., 28, 1341-1348, doi:10.1002/esp.590, 2003.

Gabet, E. J.: Late Cenozoic uplift of the Sierra Nevada, California? A critical analysis of the geomorphic evidence, Am. J. Sci., 314, 1224-1257, doi:10.2475/08.2014.03, 2014.

Gabet, E. J. and Mudd, S. M.: Bedrock erosion by root fracture and tree throw: A coupled biogeomorphic model to explore the humped soil production function and the persistence of hillslope soils, J. Geophys. Res., 115, F04005, doi:10.1029/2009JF001526, 2010.

Gilbert, G. K.: Report on the geology of the Henry Mountains: Geographical and geological survey of the rocky mountain region, US Government print-off, Washington, D.C., p. 160, 1877.

Granger, D. E., Kirchner, J. W., and Finkel, R.: Spatially averaged long-term erosion rates measured from in situ-produced cosmogenic nuclides in alluvial sediment, J. Geol., 104, 249-257, doi:10.1086/629823, 1996.

Heimsath, A. M., Chappell, J., Dietrich, W. E., Nishiizumi, K., and Finkel, R. C.: Late Quaternary erosion in southeastern Australia: A field example using cosmogenic nuclides, Quatern. Int., 8385, 169-185, doi:10.1016/S1040-6182(01)00038-6, 2001.

Heller, P. L., Beland, P. E., Humphrey, N. F., Konrad, S. K., Lynds, R. M., McMillan, M. E., Valentine, K. E., Widman, Y. A., and Furbish, D. J.: Paradox of downstream fining and weatheringrind formation in the lower Hoh River, Olympic Peninsula, Washington, Geology, 29, 971-974, 2001.

Hobley, D. E. H., Sinclair, H. D., Mudd, S. M., and Cowie, P. A.: Field calibration of sediment flux dependent river incision, J. Geophys. Res., 115, F04017, doi:10.1029/2010JF001935, 2011.

Hovius, N., Stark, C. P., and Allen, P. A.: Sediment flux from a mountain belt derived by landslide mapping, Geology, 25, 231-234, doi:10.1130/00917613(1997)025<0231:SFFAMB>2.3.CO;2, 1997.

Hurst, M. D., Mudd, S. M., Walcott, R., Attal, M., and Yoo, K.: Using hilltop curvature to derive the spatial distribution of erosion rates, J. Geophys. Res., 117, F02017, doi:10.1029/2011JF002057, 2012.

Kellerhals, R. and Bray, D. I.: Sampling procedures for coarse fluvial sediments, J. Hydraul. Div.-ASCE, 97, 1165-1180, 1971.

Knighton, A. D.: Longitudinal changes in the size and shape of stream bed material: evidence of variable transport conditions, Catena, 9, 25-34, 1982.

Lamb, M. P., Scheingross, J. S., Amidon, W. H., Swanson, E., and Limaye, A.: A model for fire-induced sediment yield by dry ravel in steep landscapes, J. Geophys. Res., 116, F03006, doi:10.1029/2010JF001878, 2011.

Lamb, M. P., Levina, M., DiBiase, R. A., and Fuller, B. M.: Sediment storage by vegetation in steep bedrock landscapes: Theory, experiments, and implications for postfire sediment yield, J. Geophys. Res., 118, 1147-1160, doi:10.1002/jgrf.20058, 2013.

Lane, S. N., Tayefi, V., Reid, S. C., Yu, D., and Hardy, R. J.: Interactions between sediment delivery, channel change, climate change and flood risk in a temperate upland environment, Earth Surf. Proc. Land., 32, 429-446, 2007.
Lavé, J. and Burbank, D.: Denudation processes and rates in the Transverse Ranges, southern California: Erosional response of a transitional landscape to external and anthropogenic forcing, J. Geophys. Res., 109, F01006, doi:10.1029/2003JF000023, 2004.

Lohse, K. A. and Dietrich, W. E.: Contrasting effects of soil development on hydrological properties and flow paths, Water Resour Res., 41, W12419, doi:10.1029/2004WR003403, 2005.

Maher, K.: The dependence of chemical weathering rates on fluid residence time, Earth Planet. Sc. Lett., 294, 101-110, doi:10.1016/j.eps1.2010.03.010, 2010.

Marshall, J. A. and Sklar, L. S.: Mining soil databases for landscape-scale patterns in the abundance and size distribution of hillslope rock fragments, Earth Surf. Proc. Land., 37, 287-300, doi:10.1002/esp.2241, 2012.

Matsushi, Y. and Matsuzaki, H.: Denudation rates and threshold slope in a granitic watershed, central Japan, Nucl. Instrum. Meth. Phys. Res. B, 268, 1201-1204, 2010.

Michael, N. A., Whittaker, A. C., Carter, A., and Allen, P. A.: Volumetric budget and grain-size fractionation of a geological sediment routing system: Eocene Escanilla Formation, south-central Pyrenees, Geol. Soc. Am. Bull., 126, 585-599, doi:10.1130/B30954.1, 2014.

Mudd, S. M. and Furbish, D. J.: Using chemical tracers in hillslope soils to estimate the importance of chemical denudation under conditions of downslope sediment transport, J. Geophys. Res., 111, F02021, doi:10.1029/2005JF000343, 2006.

Mudd, S. M. and Yoo, K.: Reservoir theory for studying the geochemical evolution of soils, J. Geophys. Res., 115, F03030, doi:10.1029/2009JF001591, 2010.

Parker, G.: Selective sorting and erosion of river gravel, II: Applications, J. Hydraul. Eng.-ASCE, 117, 150-171, 1991.

Riebe, C. S., Kirchner, J. W., Granger, D. E., and Finkel, R. C.: Erosional equilibrium and disequilibrium in the Sierra Nevada, inferred from cosmogenic $\mathrm{Al}-26$ and $\mathrm{Be}-10$ in alluvial sediment, Geology, 28, 803-806, 2000.

Riggins, S. G., Anderson, R. S., Anderson, S. P., and Tye, A. M.: Solving a conundrum of a steady-state hilltop with variable soil depths and production rates, Bodmin Moor, UK, Geomorphology, 128, 73-84, doi:10.1016/j.geomorph.2010.12.023, 2011.

Riley, K. L., Bendick, R., Hyde, K. D., and Gabet, E. J.: Frequency-magnitude distribution of debris flows compiled from global data, and comparison with post-fire debris flows in the western U.S., Geomorphology, 191, 118-128, doi:10.1016/j.geomorph.2013.03.008, 2013.

Roering, J. J., Kirchner, J. W., and Dietrich, W. E.: Evidence for nonlinear, diffusive sediment transport on hillslopes and implications for landscape morphology, Water Resour. Res., 35, 853 870, 1999.

Roering, J. J., Kirchner, J. W., Sklar, L. S., and Dietrich, W. E.: Hillslope evolution by nonlinear creep and landsliding: An experimental study, Geology, 29, 143-146, 2001.

Roering, J. J., Perron, J. T., and Kirchner, J. W.: Functional relationships between denudation and hillslope fonn and relief, Earth Planet. Sc. Lett., 264, 245-258, 2007.

Roering, J. J., Marshall, J., Booth, A. M., Mort, M., and Jin, Q. S.: Evidence for biotic controls on topography and soil production, Earth Planet. Sc. Lett., 298, 183-190, 2010.

Saucedo, G. J. and Wagner, D. L. Geologic map of the Chico quadrangle 1:250,000, Regional Geologic Map Series, Map 
no. 7A, California Department of Conservation, Division of Mines and Geology, http://ngmdb.usgs.gov/Prodesc/proddesc_ 63087.htm (last access: March 2015), 1992.

Schoklitsch, A.: Handbuch des Wasserbaues, 3rd Edn., SpringerVerlag, Vienna, 1962.

Sklar, L. S. and Dietrich, W. E.: A mechanistic model for river incision into bedrock by saltating bed load, Water Resour. Res., 40, W06301, doi:10.1029/2003WR002496, 2004.

Sklar, L. S., Dietrich, W. E., Foufoula-Georgiou, E., Lashermes, B., and Bellugi, D.: Do gravel bed river size distributions record channel network structure?, Water Resour. Res., 42, W06D18, doi:10.1029/2006WR005035, 2006.

Small, E., Anderson, R., and Hancock, G.: Estimates of the rate of regolith production using ${ }^{10} \mathrm{Be}$ and ${ }^{26} \mathrm{Al}$ from an Alpine hillslope, Geomorphology, 27, 131-150, 1999.

Snyder, N. P., Whipple, K. X., Tucker, G. E., and Merritts, D. J.: Channel response to tectonic forcing: field analysis of stream morphology and hydrology in the Mendocino triple junction region, northern California, Geomorphology, 53, 97-127, 2003.

Stock, G. M., Anderson, R. S., and Finkel, R. C.: Pace of landscape evolution in the Sierra Nevada, California, revealed by cosmogenic dating of cave sediments, Geology, 32, 193-196, 2004.

Sweeney, K. E., Roering, J. J., Almond, P., and Reckling, T.: How steady are steady-state landscapes? Using visible-near-infrared soil spectroscopy to quantify erosional variability, Geology, 40, 807-810, doi:10.1130/G33167.1, 2012.

Wakabayashi, J. and Sawyer, T. L.: Stream incision, tectonics, uplift, and evolution of topography of the Sierra Nevada, California, J. Geol., 109, 539-562, 2001.

Wells, T., Hancock, G., and Fryer, J.: Weathering rates of sandstone in a semi-arid environment (Hunter Valley, Australia), Environ. Geol., 54, 1047-1057, doi:10.1007/s00254-007-0871-y, 2008.

West, A. J., Galy, A., and Bickle, M.: Tectonic and climatic controls on silicate weathering, Earth Planet. Sc. Lett., 235, 211228, doi:10.1016/j.epsl.2005.03.020, 2005.
Whipple, K. X. and Tucker, G. E.: Implications of sediment-fluxdependent river incision models for landscape evolution, J. Geophys. Res., 107, 2039, doi:10.1029/2000JB000044, 2002.

White, A. and Brantley, S.: The effect of time on the weathering of silicate minerals: why do weathering rates differ in the laboratory and field?, Chemical Geology, 202, 479-506, 2003.

Whitaker, A. C. and Potts, D. F.: Analysis of flow competence in an alluvial gravel bed stream, Dupuyer Creek, Montana, Water Resour. Res., 43, W07433, doi:10.1029/2006WR005289, 2007.

Whittaker, A. C., Cowie, P. A., Attal, M., Tucker, G. E., and Roberts, G. P.: Contrasting transient and steady-state rivers crossing active normal faults: new field observations from the Central Apennines, Italy, Basin Research, 19, 529-556, doi:10.1111/j.1365-2117.2007.00337.x, 2007.

Whittaker, A. C., Attal, M., Cowie, P. A., Tucker, G. E., and Roberts, G. P.: Decoding temporal and spatial patterns of fault uplift using transient river long profiles, Geomorphology, 100, 506-526, doi:10.1016/j.geomorph.2008.01.018, 2008.

Whittaker, A. C., Attal, M., and Allen, P. A.: Characterizing the origin, nature and fate of sediment exported from catchments perturbed by active tectonics, Basin Research, 22, 809-828, doi:10.1111/j.1365-2117.2009.00447.x, 2010.

Wolcott, J.: Nonfluvial control of bimodal grain-size distributions in river-bed gravels, J. Sediment. Petrol., 58, 979-984, 1988.

Yoo, K. and Mudd, S. M.: Discrepancy between Mineral Residence Time and Soil Age: Implications for the Interpretation of Chemical Weathering Rates, Geology, 36, 35-38, doi:10.1130/G24285A.1, 2008.

Yoo, K., Weinmann, B., Mudd, S. M., Hurst, M. D., Attal, M., and Maher, K.: Evolution of hillslope soils: The geomorphic theater and the geochemical play, Appl. Geochem., 26, S149-S153, doi:10.1016/j.apgeochem.2011.03.054, 2011. 